Published in final edited form as:

Adv Drug Deliv Rev. 2008 January 14; 60(2): 243-262.

\title{
Engineering Cartilage Tissue
}

\author{
Cindy Chung and Jason A. Burdick ${ }^{*}$ \\ Department of Bioengineering, University of Pennsylvania, 240 Skirkanich Hall, 210 S. $33^{\text {rd }}$ Street, \\ Philadelphia, PA 19104
}

\begin{abstract}
Cartilage tissue engineering is emerging as a technique for the regeneration of cartilage tissue damaged due to disease or trauma. Since cartilage lacks regenerative capabilities, it is essential to develop approaches that deliver the appropriate cells, biomaterials, and signaling factors to the defect site. The objective of this review is to discuss the approaches that have been taken in this area, with an emphasis on various cell sources, including chondrocytes, fibroblasts, and stem cells.

Additionally, biomaterials and their interaction with cells and the importance of signaling factors on cellular behavior and cartilage formation will be addressed. Ultimately, the goal of investigators working on cartilage regeneration is to develop a system that promotes the production of cartilage tissue that mimics native tissue properties, accelerates restoration of tissue function, and is clinically translatable. Although this is an ambitious goal, significant progress and important advances have been made in recent years.
\end{abstract}

\section{Keywords}

Cartilage; Tissue Engineering; Biomaterials; Stem Cells; Regeneration

\section{Introduction}

Tissue engineering is an evolving field that has the potential to provide permanent solutions to tissue damage and tissue loss to millions of people each year [1]. The basic approach to tissue engineering involves the use of cells, scaffolds, and signaling factors, alone or in combination. Engineering cartilage is no exception to this approach. Cartilage, a predominantly avascular, aneural, and alymphatic tissue, is composed of sparsely distributed chondrocytes embedded within a dense extracellular matrix (ECM). This ECM is composed of primarily type II collagen and proteoglycans that provide the tissue with sufficient mechanical properties for function in vivo. Due to its limited ability to self repair, cartilage is an ideal candidate for tissue engineering.

The concept of cell-based therapies for cartilage regeneration and repair is not new. Autologous chondrocyte transplantation (ACT) has been used clinically to repair both craniofacial and articular cartilage defects. Since 1987, ACT has been used to treat full-thickness chondral defects in more than 12,000 patients worldwide [2]. This approach involves harvesting small biopsies of cartilage from the patient in a minimally invasive manner, isolating chondrocytes from the donor tissue, and expanding the cells in vitro. These cells are then delivered to the

\footnotetext{
*Corresponding author. Tel.: 215898 8537; fax: 215573 2071, E-mail address: burdick2@ seas.upenn.edu (J.A. Burdick). This review is part of the Advanced Drug Delivery Reviews theme issue on "Emerging Trends in Cell-based Therapies"

Publisher's Disclaimer: This is a PDF file of an unedited manuscript that has been accepted for publication. As a service to our customers we are providing this early version of the manuscript. The manuscript will undergo copyediting, typesetting, and review of the resulting proof before it is published in its final citable form. Please note that during the production process errors may be discovered which could affect the content, and all legal disclaimers that apply to the journal pertain.
} 
cartilage defect site under a periosteum flap to produce new cartilage tissue. Due to the low cell density of mature cartilage tissue, an inherent limitation of ACT is the low number of cells obtained through the biopsy. As research in the field of cartilage tissue engineering advances, new techniques, cell sources, and biomaterials are being employed to overcome these limitations and enhance and improve the quality of the repair.

Although new technology is important for all cartilage types, regenerative techniques for articular cartilage (hyaline) defects that result from traumatic injury or degenerative joint diseases, would probably have the largest impact on patients. With an aging population and the growing problem of obesity, the number of osteoarthritis cases is estimated to boom in the coming years. Currently, more than 250,000 knee and hip replacements are performed in the United States each year for end-stage disease joint failure, and many other patients suffer from less severe cartilage damage [3]. Also, with a more active adult population, cartilage damage resulting from sports injuries can often result in premature cartilage degeneration. The popular treatments for articular cartilage repair include: microfracture, mosaicplasty, ACT, and osteochondral allograft transplantation. Although these techniques have successfully relieved pain and improved joint function, each are plagued with their disadvantages that can deter their long-term clinical application [2]. For instance, cartilage produced from these techniques is often composed of type I collagen (characteristic of fibrocartilage), which is biochemically and biomechanically inferior to hyaline cartilage. In addition, the repaired tissue often lacks the structure of native cartilage. Other drawbacks to current treatments include donor site morbidity, complicated surgical procedures, and risks of infection and graft rejection.

To date, the properties and structure of native cartilage have not been entirely mimicked by any engineered replacement. Thus, the objective of this review is to provide an overview of the emerging trends in cartilage tissue engineering, with an emphasis on cell source, as it is an essential component to any cartilage repair technique. The use of scaffolds as vehicles for cell delivery and the addition of stimulatory factors will also be discussed with respect to their effects on cell behavior and tissue formation. The wide range of approaches investigated for cartilage tissue engineering is summarized in Figure 1. Although it is not possible to cover every cartilage tissue engineering study in detail, this review represents the major steps that are being taken towards the production of engineered cartilaginous tissue.

\section{Cell Source}

The optimal cell source for cartilage tissue engineering is still being identified. Chondrocytes, fibroblasts, stem cells, and genetically modified cells have all been explored for their potential as a viable cell source for cartilage repair (Table 1). Chondrocytes are the most obvious choice since they are found in native cartilage and have been extensively studied to assess their role in producing, maintaining, and remodeling the cartilage ECM. Also, fibroblasts are easily obtained in high numbers and can be directed toward a chondrogenic phenotype [4]. Recent work has focused more on stem cells, which have multi-lineage potential and can be isolated from a plethora of tissues. These progenitor cells can be expanded through several passages without loss of differentiation potential. Additionally, all of these cells can be modified genetically to induce or enhance chondrogenesis. The goal is to find an ideal cell source that can be easily isolated, is capable of expansion, and can be cultured to express and synthesize cartilage-specific molecules (e.g., type II collagen and aggrecan).

\subsection{Chondrocytes}

Differentiated chondrocytes are characterized by a rounded morphology and the production of ECM molecules such as type II collagen and sulfated glycosaminoglycans (GAGs).

Chondrocytes maintain and remodel cartilage matrix tissue by a careful balance of catabolic and anabolic processes involving matrix metalloproteinases (MMPs) and tissue inhibitors of 
metalloproteinases (TIMPs). Preserving these characteristics is crucial for chondrocytes to be used as a cell source for cartilage repair. A variety of key issues involving the use of chondrocytes as a cell source for clinical application will be covered in this section.

2.1.1. Chondrocyte Expansion-As mentioned above, one of the major challenges for cartilage tissue engineering is obtaining sufficient cell numbers to fill a clinically relevant defect. Chondrocytes are limited in number, comprising only 5 to $10 \%$ of cartilage tissue, and thus, need to be expanded prior to use. Unfortunately, monolayer expansion causes dedifferentiation of chondrocytes, which is characterized by decreased proteoglycan synthesis and type II collagen expression and increased type I collagen expression. Changes in the expression of collagens [5,6], integrins [7], growth factors [8], and matrix modulators [9] and the activation of signaling proteins like src homology collagen (SHC) and extracellular signalregulated kinase 1/2 (Erk1/2) [10] accompany dedifferentiation and are used as early markers or signs of irreversibly dedifferentiated cells. Darling et al, showed changes in articular chondrocyte gene expression (type I and type II collagen, aggrecan, and superficial zone protein) as early as the first passage, even when encapsulated in alginate beads [11]. Furthermore, the use of passaged cells can lead to compromised tissue quality with decreased biochemical content and mechanical properties [12].

A variety of substrates [13-15] and growth factors (GFs) like fibroblast growth factor-2 (FGF-2) [16] have been used to prevent or slow chondrocyte dedifferentiation in monolayer cultures. For instance, the gene expression of chondrocytes was similar when grown on aggrecan-coated polystyrene to cells redifferentiated in 3D agarose gels [15]. However, substrates coated with fibronectin and type I/II collagen were unable to prevent the loss of phenotype [14,15]; though type II collagen-expanded human articular chondrocytes are able to regain their phenotype when cultured in pellets in chondrogenic medium and expressed higher mRNA for type II collagen and greater GAG production over tissue culture polystyreneexpanded chondrocytes [13].

Three dimensional cultures, such as agarose [17], alginate beads [18], and fibrin glue [19] may preserve the chondrocyte phenotype (i.e., increased aggrecan production and type II collagen expression). However, some complications may be encountered during cell recovery [19]. Thermoreversible hydrogels, like poly(N-isopropylacrylamide-co-acrylic acid) (PNiPAAmco-Aac), have also been used to expand chondrocytes without loss of phenotype, and the thermoreversible nature of the gels allows for easy cell recovery [20]. Once expanded, differentiated chondrocytes can be released and seeded onto other scaffolds. Also, Malda et al showed that nasal and articular chondrocytes could be expanded without dedifferentiation on macroporous gelatin CultiSher and Cytodex-1 microcarriers, respectively, with doubling times comparable to standard T-flask expansion [21,22].

In addition, a variety of methods have been employed to redifferentiate chondrocytes including the use of 3D scaffolds, bioreactors (e.g., rotating wall reactors) [23], reduced oxygen tension [24], and with GFs like transforming growth factor- $\beta$ (TGF- $\beta$ ), FGF, and insulin-like growth factor (IGF) [25]. In addition, co-culture with up to $20 \%$ of primary cells has up-regulated expresson of aggrecan, type II collagen, and transcription factor Sox 9, while down-regulating type I collagen [26]. Finally, redifferentiation can be affected by surface chemistry. Woodfield et al showed that a substrate with low adhesion supported a chondrocytic phenotype, where cells exhibited a round morphology and minimal expression of the $\alpha 5 \beta 1$ fibronectin integrin [27].

2.1.2. Zonal Organization-Articular cartilage is an anisotropic tissue composed of a superficial, middle, and deep zone. Each distinct zone varies in structure and function, responds to different stimuli, and secretes different proteins [11]. Chondrocytes isolated from each zone 
have unique growth rates [28], gene expression [29,30], and levels of biosynthesis [31,32]. For instance, chondrocytes isolated from the superficial layer exhibit increased superficial zonal protein (SZP) expression, while chondrocytes from middle and deep zones exhibit increased type II collagen expression [29,30]. An increase in GAG and collagen is observed with increased depth, providing the deep zone with superior mechanical properties compared to the superficial zone [31,32]. Typically, articular cartilage engineering studies use homogenous cell mixtures from immature animals, which yield chondrocytes that produce large amounts of ECM, but lack zonal organization. Recently, more attention has been focused on the differences among these zones, and methods of recreating zonal organization in engineered constructs are being explored, including multilayer hydrogels and porous gradient scaffolds.

Bilayer poly(ethylene oxide) diacrylate (PEODA) [33] and multilayer poly(ethylene glycol) diacrylate (PEGDA) [34] hydrogels have been engineered to support the growth of isolated articular chondrocyte subpopulations. Using sequential photopolymerization of multiple layers, cell populations can be distributed in layers throughout a 3D construct. These multilayered constructs exhibited similar cell and ECM distribution patterns to that of native cartilage [34] and the bilayer constructs expressed greater shear and compressive strengths than homogenous cell-seeded constructs [33]. In addition, the influence of anisotropic pore architecture on zonal organization has also been investigated. Porous poly(ethylene glycol)terephthalate-poly(butylene terephthalate) (PEGT/PBT) copolymer scaffolds with either homogenous pores or pore-size gradients were developed using a 3D fiber deposition technique. In vitro cultures yielded inhomogenous cell distributions and zonal distributions of GAGs and type II collagen similar to that of native cartilage [35]. The regeneration of zonal organization of engineered cartilage may be important towards the development of functional tissue.

2.1.3. Chondrocyte Sources-Many studies have focused on the use of articular chondrocytes as a viable cell source for cartilage repair. However, the harvesting of joint cartilage is a highly invasive procedure accompanied by the potential for donor site morbidity and loss of function. In addition, low cell yields, low mitotic rates, and low bioactivity can further limit the use of articular chondrocytes in a clinical setting. With these limitations in mind, other potential autologous chondrocyte sources in the body including auricular, nasoseptal and costal cartilage are being investigated. Known differences among these chondrocyte sources in terms of function, structure, and composition make each unique in elaborating an ECM with discrete biochemical, physical and biomechanical properties; and thus, the eventual choice of chondrocyte depends on the desired application.

Auricular cartilage is an elastic cartilage found in the ear and epiglottis. In a study by van Osch et al, human auricular chondrocytes were investigated for their potential use in cartilage repair [36]. Compared to articular cartilage, auricular chondrocyte isolation resulted in cell yields 2fold higher and cell proliferation rates 4 times faster, while retaining chondrogenic potential when cultured in alginate beads. With in vivo culture, constructs exhibited proteoglycan-rich matrices with positive type II collagen staining and faint elastin staining. In addition, auricular chondrocyte samples produced neocartilage with greater biochemical and histological similarity to that of native cartilage than articular counterparts when implanted in vivo [37].

Nasoseptal cartilage is a hyaline cartilage that has received attention for applications in craniofacial and plastic surgeries. Adult nasal chondrocytes are capable of generating a matrix with high collagen II/I ratio and GAG accumulation [38]. In addition, nasal chondrocytes proliferate 4 times faster than articular chondrocytes in monolayer [38], and can be seeded at very low seeding densities with an 838-fold expansion in one passage without dedifferentiation [39]. Also, nasal chondrocytes have been successfully cultured as macroaggregates [40], on collagen microcarriers [41], and in a number of scaffold systems including alginate [18], PEGT/ 
PBT block copolymer [42], methylcellulose [43], and HYAFF(R)11 [44], a hyaluronic acid (HA) derivative. These cells show good viability and produce an ECM-rich tissue with high expression of type II collagen under appropriate culture conditions [40-44]. Additional studies show that nasal chondrocytes respond to growth factors like TGF- $\beta 1$, FGF-2, bone morphogenic protein-2 (BMP-2), and IGF-1 $[45,46]$ in serum-free culture with enhanced proliferation and/or matrix deposition.

In a chondrocyte source comparison study, bovine nasal, articular, costal, and auricular chondrocytes were grown on poly(L-lactide- $\varepsilon$-caprolactone) scaffolds for 4 weeks [47]. Growth rates and gene expression varied with cell type, where the highest expression of type II collagen and aggrecan was found for costal chondrocytes, followed by nasoseptal, articular, and auricular chondrocytes. The construct size also varied, with auricular cell constructs having the largest diameter and costal constructs the greatest thickness. Another study looked at the effect of GFs on auricular, nasal, and costal chondrocytes and showed that all cell types exhibited increased proliferation, GAG/DNA content, and up-regulation of type II collagen expression after GF supplementation. However, redifferentiation was only achieved in auricular and nasal chondrocyte cell pellets [48]. Furthermore, Johnson et al demonstrated that articular, auricular, and costal chondrocytes were all able to form new cartilaginous matrix when cultured in fibrin glue-cartilage composites in vivo [49].

\subsubsection{Aged, Osteoarthritic, Cryogenically-Preserved Chondrocytes-As}

mentioned previously, efforts in cartilage regeneration have focused primarily on chondrocytes isolated from immature animals. These neonatal and young chondrocytes have faster growth rates, the capacity for rapid in vitro expansion, and greater chondrogenic potential (increased Sox 9 and type II collagen expression) over chondrocytes from older donors [30]. Although these traits are advantageous for expanding chondrocytes and producing ECM-rich neocartilage, the use of immature cartilage in a clinical setting for older patients may not be possible. Thus, the proliferative and chondrogenic potential of adult, osteoarthritic, and even cryogenically preserved chondrocytes are also explored as alternative cell sources.

In agarose gels, older chondrocytes exhibit decreased cell yields [50], lower proliferation rates [30,50-52], diminished chondrogenic potential [30,52] and decreased tensile stiffness [53] when compared to fetal and young chondrocytes. However, these limitations can be countered with the addition of GFs like TGF- $\beta 1$ [50], TGF- $\beta 2$ [52], FGF-2 [50], platelet-derived growth factor (PDGF) [50], and/or IGF-1 [52]. Also, culture in serum-free media resulted in increased proliferation rates, a greater ratio of type II to type I collagen, and decreased expression of MMP-3, which is commonly associated with matrix degradation [51]. When articular chondrocytes from young and old sheep were encapsulated in fibrin glue and cultured subcutaneously in nude mice for 7 and 12 weeks, constructs from old and young donors exhibited similar patterns of ECM deposition, with increasing DNA, GAG, and hydroxyproline content over culture time [54]. Other culture environments like the rotating wall vessel (RWV) with controlled oxygen tension were used to show that aged articular chondrocytes were capable of aggregating and forming solid tissue with positive staining for type II collagen after 12 weeks [55]. Research still needs to be performed to optimize culture techniques for these aged cells and to define their limitations and potential use in a clinical setting.

Osteoarthritic (OA) chondrocytes have also been investigated for their potential in cartilage repair. Both in vitro and in vivo culture of OA cells on $\mathrm{HYAFF}(\mathrm{R}) 11$ yielded positive staining for type II collagen and sulfated proteoglycans and negative staining for type I collagen [56]. Furthermore, OA articular chondrocytes can be transduced with Sox 9 via adenoviral and retroviral vectors to stimulate type II collagen expression and deposition in both monolayer and alginate bead cultures [57]. Finally, cryogenically preserved cells may provide an alternative source for cartilage regeneration. Septal chondrocytes frozen for 3 years showed 
evidence of hyaline growth on knitted polygalactin 910 woven mesh scaffolds after 6 weeks of culture in a slowly turning lateral vessel [58].

\subsection{Fibroblasts}

Skin presents a minimally invasive, relatively abundant source of fibroblasts for tissue engineering. Although the direct transplantation of fibroblasts on PLA meshes in a cartilage defect leads to fibrous tissue production [59], fibroblasts can be redirected towards a chondrocytic phenotype when cultured under the appropriate conditions. Human dermal fibroblasts pretreated with IGF-1 and cultured on aggrecan form dense aggregates that stain positive for GAGs and type II collagen [60]. In addition, dermal fibroblasts cultured in the presence of demineralized bone [61], or grown as high density micromass cultures in the presence of lactic acid [4] express cartilage specific matrix proteins like aggrecan and type II collagen. Also, fibroblasts expressing active TGF- $\beta 1$ were injected into cartilage defects and showed evidence of newly formed hyaline cartilage after 6 weeks [62]. Recently, Deng et al isolated a subpopulation of skin-derived cells called dermis-isolated, aggrecan-sensitive (DIAS) cells [63]. These cells up-regulate aggrecan, cartilage oligomeric matrix protein (COMP), and type II collagen over unpurified dermis cells. Furthermore, 3D self-assembled constructs developed from DIAS cells show evidence of rich cartilage-specific ECM.

\subsection{Stem Cells}

Recently, stem cells have generated significant interest in cartilage tissue engineering as an alternative to autologous chondrocytes. Stem cells are pluripotent cells that can be differentiated down multiple cell lineages given the appropriate cues. In 1998, bone-marrow derived stem cells were found to undergo chondrogenesis when cultured in cell aggregates in the presence of TGF- $\beta 1$ [64]. More recently, adipose tissue has been identified as a source of stem cells that can be isolated under local anesthesia with minimal discomfort [65]. Other sources of stem cells investigated for cartilage repair include muscle [66,67], synovium [68-70], and periosteum [71].

2.3.1. Bone Marrow-derived Stem Cells-Bone marrow-derived stem cells (BMSCs) undergo chondrogenesis in a variety of culture conditions, which typically involves induction with TGF- $\beta$ and a 3D culture environment (e.g., cell pellets and micromasses). For in vitro culture, the addition of TGF- $\beta$ has generally stimulated enhanced chondrogenesis, regardless of culture method or scaffold; however, the degree of chondrogenesis is scaffold dependent [72]. For example, Coleman et al showed increased sulfated GAG production by BMSCs in alginate over agarose gels [72]. To date, numerous scaffolds have been used in conjunction with TGF- $\beta$ and chondrogenic media supplementation towards the chondrogenesis of BMSCs including: agarose [72,73], alginate [72], poly(ethylene glycol) (PEG) [74], poly(glycolic acid) (PGA) [75], silk [76,77], poly(DL-lactic-co-glycolic acid)-collagen (PLGA-collagen) meshes [78], gelatin/chondroitin/HA tri-copolymer [79], and electrospun polycaprolactone (PCL) [80]. Evidence of chondrogenesis was characterized by enhanced type II collagen and aggrecan expression and accumulation. In addition to TGF- $\beta$, the cycling of growth factors (BMP- 6 and IGF-1) during in vitro culture also affects chondrogenesis [81]. In addition, cultures of BMSCs with components of the joint cavity, like synovial fluid or synovial cells, induce chondrogenesis in vitro [82].

For in vivo delivery, a controlled method of TGF- $\beta$ introduction is usually employed to induce chondrogenesis. Alginate beads loaded with TGF- $\beta 1$ exhibited sustained release for 35 days in PBS at $37^{\circ} \mathrm{C}$ and induced chondrogenesis [83]. Others have loaded TGF- $\beta 1$ in gelatin microspheres, which enhanced MSC repair in a full-thickness defect over in vitro differentiated cells [84]. Using a gene therapy approach, human MSCs lipofected with TGF- $\beta 2$ showed an upregulation of type II collagen and aggrecan expression and enhanced matrix synthesis for 
up to 4 weeks [85]. In addition, differentiation in vivo without GF release has also been investigated. In these cases, BMSCs rely on the scaffold and the natural in vivo environment for differentiation cues. Various scaffolds without incorporated GF release have been investigated including: HA [86], PGA [87], and beta-tricalcium phosphate ceramic [85] scaffolds. One study showed that cryopreserved human BMSCs were capable of producing cartilaginous tissue when subcultured on PGA scaffolds in vitro, followed by implantation in nude mice for 10 weeks [75]. Furthermore, osteoarthritic BMSCs maintained their differentiation potential during monolayer expansion in the presence of FGF-2 [88]. Additionally, the co-culture of BMSCs and chondrocytes increased cell proliferation and cartilaginous ECM deposition with positive expression for type II collagen [89,90]. This may be attributed to GF secretion and cell-cell interactions [89] or a chondrogenic microenvironment provided by the chondrocytes to promote the in vivo chondrogenesis of MSCs [90].

However, a limitation of BMSCs is the mechanical integrity of the matrix they produce [91]. In a long-term agarose culture, chondrogenesis was observed in the MSC-laden gels, but the amount of matrix produced and mechanical properties were inferior to that produced by chondrocytes from the same donor [91]. The GAG content and the equilibrium modulus of MSC-laden gels plateaued with time, suggesting diminished chondrogenic capacity rather than delayed differentiation.

2.3.2. Adipose-derived Stem Cells-A fibroblast-like population of stem cells can be isolated from adipose tissue and cultured in vitro for an extended period with stable expansion and low levels of senescence [65]. These cells are mesenchymal in origin, as determined by immunofluorescence and flow cytometry, and are capable of differentiating into chondrocytes in the presence of TGF- $\beta$, ascorbate, and dexamethasone in combination with a $3 \mathrm{D}$ culture environment [65,92]. Differentiation has been achieved in high density micromass cultures [93,94], and in alginate [95-97], agarose [95], and collagen-based scaffolds [95,98]. During in vitro culture, chondro-induced adipose-derived stem cells (ADSCs) produced cartilagespecific matrix proteins and exhibited an increase in equilibrium compressive and shear moduli with accumulation of sulfated-GAGs [95]. In monolayer culture, these cells exhibited prehypertrophic alteration in late stages after induction [97]. Masuoka et al showed hyaline cartilage repair in full-thickness defects in rabbits using ADSCs and an atelopeptide type I collagen honeycomb-shaped scaffold [98]. In addition, a novel elastin-like polypeptide (ELP) has been shown to promote chondrogenic differentiation of ADSCs without media supplements [99]. After 2 weeks of culture, similar accumulations of sulfated GAGs and type II collagen were observed in constructs cultured in chondrogenic and standard media.

The use of GFs, like FGF-2 and BMP-6, also affects the chondrogenesis of ADSCs. FGF-2 increases cell proliferation and enhances chondrogenesis by inducing N-Cadherin, FGF-R2, and Sox 9 in micromass culture [94]. BMP-6 alone also upregulates the expression of aggrecan (205-fold) and type II collagen (38-fold) in alginate culture [100]. Despite their ability to undergo chondrogenesis, comparative studies suggest that ADSCs have lower chondrogenic potential than stem cells isolated from other sources such as bone marrow [69,101-103]. A lower accumulation of cartilage-specific matrix proteins $[69,101,102]$ and lower type II collagen gene expression $[101,103]$ over other cell types suggests that more research needs to be done to optimize the chondrogenic potential of ADSCs.

2.3.3. Other Adult Stem Cells-Besides bone marrow and adipose tissue, muscle, synovium, and periosteum are other sources of adult stem cells being explored for applications in cartilage repair. Nawata et al generated cartilaginous tissue with muscle-derived stem cells (MDSCs) using type I collagen scaffolds with the addition of BMP-2 and diffusion chambers [66]. These constructs were then implanted into full thickness rat defects, and resembled mature 
cartilage after 5 weeks. MDSC-seeded type I collagen gels performed similarly to chondrocyteseeded constructs in full thickness defects [67].

Stem cells isolated from synovium have been cultured in micromasses [68], and in alginate [68] and collagen gels [70] to produce cartilaginous tissue. In alginate culture, BMP-2 stimulates a dose-dependent expression of Sox 9, type II collagen, and aggrecan in these encapsulated cells that was comparable to articular chondrocytes [68]. However, this was not true for TGF- $\beta$ isoforms, suggesting that the effects of GFs may differ depending on stem cell source. In a comparative study of mesenchymal stem cells (MSCs) isolated from 5 different tissue sources, synovium-derived stem cells were shown to have the greatest chondrogenic potential [69]. In fracture healing and callus distraction, periosteum-derived stem cells (PDSCs) differentiated into chondrocytes during endochondral ossification. Although the factors regulating this process are still unclear, GFs assist periosteum-derived stem cell chondrogenesis. In an in vitro agarose culture, the addition of IGF-1 improved PDSC chondrogenesis in a dose-dependent manner and was improved with the addition of TGF- $\beta 1$ [71].

2.3.4. Embryonic Stem Cells-Embryonic stem cells (ESCs) are obtained from the inner cell mass of blastocyst stage embryos. These cells are capable of many doublings and have the ability to differentiate into all somatic cell types. Although ESCs are appealing as a cell source for their vast proliferation capabilities, difficulties in ESC selection and purity, as well as antigenicity and ethical issues, may hinder their clinical use. For chondrogenesis, ESCs must pass through an aggregation stage of embryonic bodies (EBs) before differentiation. Mouse embryonic bodies encapsulated in PEG hydrogels showed chondrogenesis with upregulation of cartilage specific markers, while stimulation with TGF- $\beta 1$ resulted in basophilic ECM deposition characteristic of neocartilage [104,105]. In addition, mouse ESCs undergo chondrogenesis with the addition of BMP-2 and BMP-4, exhibiting increased Alcian blue and type II collagen staining [106]. However, different mouse embryonic stem cells lines exhibit varying degrees of spontaneous chondrogenic differentiation [107]. A study with human ESCs demonstrated that human ESC-derived EBs were capable of complete chondrogenesis from chondrogenic induction to hypertrophic maturation [108]. EB cells dissociated and plated as high-density micromasses, as well as the addition of BMP-2, accelerated and enhanced chondrogenesis with the formation of a cartilage-rich ECM composed of collagen and proteoglycans. Furthermore, co-culture of human ESCs with primary chondrocytes was shown to induce chondrogenesis, where the co-cultured cells expressed Sox 9 and type II collagen, whereas cultures of human ESCs alone did not [109]. Overall cartilage tissue engineering research with ESCs is still relatively new and as we learn more about ESCs, new strategies for purification and differentiation will be identified to fully access their potential as a viable cell source for cartilage engineering.

\section{Scaffolds}

Numerous scaffolding materials have been used for cell delivery in cartilage regeneration. The primary focus has been on polymeric materials, in forms of hydrogels, sponges, and fibrous meshes (Figure 2). Scaffolds provide a 3D environment that is desirable for the production of cartilaginous tissue. Ideally the scaffold should: 1) have directed and controlled degradation, 2) promote cell viability, differentiation, and ECM production, 3) allow for the diffusion of nutrients and waste products, 4) adhere and integrate with the surrounding native cartilage, 5) span and assume the size of the defect, and 6) provide mechanical integrity depending on the defect location. Scaffold degradation can occur hydrolytically or enzymatically, and by controlling degradation temporally and spatially, scaffolds can enhance and direct new tissue growth. For example, scaffolds with degradable and non-degradable units show improved ECM distribution compared to completely non-degradable scaffolds [110]. However, a balance 
must be found since slow degradation may impede new cartilaginous ECM production, while fast degradation may compromise structural support and shape retention. For instance, Solchaga et al showed that scaffolds with slower degradation rates yielded cartilage of greater thickness in an osteochondral defect model, but cracks and fissures were evident on the cartilage surface [111].

In designing a scaffold, cell seeding density and seeding method should be carefully considered since the appropriate numbers of cells must be used to ensure adequate cell-cell interactions. Many approaches attempt to mimic the natural condensation of cells during embryonic cartilage development by seeding in aggregates or at high densities. Higher initial seeding densities tend to facilitate greater ECM synthesis and deposition, presumably due to cell-cell interactions $[73,112,113]$. The method of seeding, statically or dynamically, can dictate cell distribution and infiltration into the scaffold. In sponge and mesh scaffolds, dynamic seeding can improve cellular distribution [112], whereas hydrogels typically support uniform cell distributions if cells are adequately suspended during gelation.

To date, a wide range of natural and synthetic materials have been investigated as scaffolding for cartilage repair. Natural polymers that have been explored as bioactive scaffolds for cartilage engineering include: alginate, agarose, fibrin, HA, collagen, gelatin, chitosan, chondroitin sulfate, and cellulose (Table 2). Natural polymers can often interact with cells via cell surface receptors and regulate or direct cell function. However, due to this interaction, these polymers may also stimulate an immune system response; thus, antigenicity and disease transfer are of concern when using these biomaterials. In addition, natural polymers may be inferior mechanically and subject to variable enzymatic host degradation. On the other hand, synthetic polymers are more controllable and predictable, where chemical and physical properties of a polymer can be modified to alter mechanical and degradation characteristics. Synthetic polymers currently explored for cartilage repair include: poly( $\alpha$-hydroxy esters), PEG, poly(NiPAAm), poly(propylene fumarates), and polyurethanes (Table 2). However, unless specifically incorporated, synthetic polymers do not benefit from direct cell-scaffold interactions, which can play a role in adhesion, cell signaling, directed degradation, and matrix remodeling. In addition, degradation byproducts may be toxic or elicit an inflammatory response. Finally, scaffold architecture also plays a major role in dictating cellular behavior. Scaffolds can be categorized into hydrogels, sponges, and fibrous meshes (Figure 2). The following sections outline the advantages and disadvantages to each scaffold structure and introduce materials that have been investigated for cartilage tissue engineering.

\subsection{Hydrogels}

Hydrogels are water swollen networks, suitable for the delivery of cells and bioactive agents. Hydrogels may be used as injectable scaffolds since they easily fill defects of any size and shape and may be implanted in a minimally invasive manner. Hydrogels support the transport of nutrients and waste, and can homogenously suspend cells in a 3D environment, where encapsulated cells typically retain a rounded morphology that may induce a chondrocytic phenotype. Hydrogels are also capable of transducing mechanical loads to exert controlled forces on encapsulated cells, similar to physiological conditions. Though their mechanical properties can be altered by crosslinking density (which may compromise cell viability) limited mechanics may be the major drawback to using hydrogels [114].

Hydrogels are crosslinked either physically or chemically. Physically crosslinked gels are held together by molecular entanglements and/or secondary forces like ionic or hydrogen bonding or hydrophobic interactions, while chemically crosslinked gels are covalently bonded.

Molecular weight, macromer concentration, method of crosslinking, crosslinking density, and mesh size dictate the physical and chemical properties of the hydrogel including: swelling ratio, mechanics, cell viability, and degradation rate. Photopolymerization is one approach to 
chemically crosslink hydrogels using ultraviolet or visible light, and provides uniform cell seeding with both spatial and temporal control over polymerization [115]. Careful screening of photoinitiating conditions has been performed to optimize cell viability within these crosslinked networks [116].

PEG is a relatively inert polymer and supports chondrogenesis when crosslinked into hydrogels [114]. Further modifications to PEG, including the addition of hydrolyzable units and bioactive peptides have improved cartilage tissue growth [110]. For instance, degradable lactic acid units have been added to PEG hydrogels to increase cell proliferation and ECM deposition [110, 114,117,118]. Recently, Lee and colleagues covalently incorporated a collagen mimetic peptide (CMP) into PEG hydrogels [119]. CMP is known to associate with type I collagen and other ECM fibers, forming physical crosslinks that can then be manipulated by cells. This study showed that PEG hydrogels conjugated with CMP limited the diffusion of exogenous type I collagen and increased ECM production by encapsulated chondrocytes. PEG has also been combined with methacrylated poly(glycerol succinic acid) dendrimers [120].

Another polymer used for cartilage tissue regeneration is HA, a linear polysaccharide found natively in cartilage. It functions as a core molecule for the binding of keratin sulfate and chondroitin sulfate in forming aggrecan in cartilage and degrades primarily by hyaluronidases found throughout the body. HA plays a role in cellular processes like cell proliferation, morphogenesis, inflammation, and wound repair [121], and may function as a bioactive scaffold, where cell surface receptors for HA (CD44, CD54, and CD168) allow for cell/scaffold interactions. For photopolymerization, HA can be modified with methacrylate groups [122, 123], and by varying the molecular weight and concentration of the modified HA, a wide range of properties can be obtained [124]. Increases in macromer concentrations significantly increased the network compressive modulus and degradation time while decreasing the swelling ratio and cell viability [124]. These variations in scaffold properties also affected neocartilage formation by auricular chondrocytes in vivo [125]. In a recent in vivo rabbit defect model, Liu et al investigated the quality of repair using HA-gelatin hydrogels seeded with MSCs. Defects with MSCs alone exhibited hyaline-like cartilage on the peripheral defect area and fibrous repair in the middle, whereas defects filled with a scaffold and MSCs resulted in elastic, firm, translucent cartilage with zonal architecture and good integration with the surrounding cartilage [126]. Chondroitin sulfate, another major constituent of cartilage, can also be photopolymerized with similar modifications to produce hydrogels that exhibit viscoelastic behavior [127]. These chondroitin sulfate based hydrogels support viable chondrocytes and can be degraded in the presence of chondroitinase ABC. Furthermore, chondroitin sulfate can be copolymerized with PEG to increase the hydrogel pore size and provide bioactive cues for encapsulated cells [127].

Fibrin glue is a natural polymer formed from the polymerization of fibrinogen with thrombin, and it elicits good biocompatibility as a wound adhesive and can facilitate cell-matrix interaction via integrin binding [128]. It is attractive as a natural scaffold because it can be made from autologous blood. However, one drawback is that gels tend to shrink in vivo. Recently, a long-term stable fibrin gel has been developed that is transparent and stable for 3 weeks [129]. This gel exhibits a broad linear viscoelastic region, withstands loads of 0.0001 to $10 \mathrm{kPa}$, and supports chondrocyte proliferation and cartilaginous ECM production while retaining its size and shape. Studies in nude mice have shown the suitability of using fibrin glue as a biomaterial, where degradation and polymerization time can be controlled by fibrinogen and thrombin concentrations, respectively [130]. Fibrin glue has also been combined with other polymers like polyurethane and improved cell seeding viability and distribution, and increased the expression of aggrecan and type II collagen [131]. 
Type I and type II collagen scaffolds have inherent biological cues that allow chondrocytes to interact and remodel the hydrogel. A type I collagen gel seeded with autologous chondrocytes has been used to treat full thickness defects in rabbits with newly regenerated cartilaginous tissue formation seen after 6 months and tissue organization after 12 months [132]. Gelatin, which is derived from collagen, is also biocompatible and can be modified to crosslink with visible light and support chondrocytes, though some potential diffusion limitations may exist [133]. Also, gelatin/alginate gels promoted chondrocyte proliferation, a rounded morphology, and expression of hyaline matrix molecules with increased spatial deposition of proteoglycans and constant expression of type II collagen [134].

Alginate is a polyanionic polymer found in brown algae, and can be crosslinked with bivalent cations to form stable ionically crosslinked gels. Alginate beads and hydrogels have been used to expand chondrocytes and induce stem cell differentiation [95-97]. Recently, investigators have modified alginate gels with synthetic adhesion peptides [135] or combined alginate with other materials to make hybrid scaffolds $[134,136,137]$. RGD-functionalized alginate has been shown to affect articular chondrocyte attachment and morphology and chondrogenesis [135, 138]. Also with increasing crosslinking density and substrate stiffness, chondrocytes grown on alginate gels exhibited a more flattened morphology with stress fibers observed via phalloidin staining [138]. Despite its advantages for studying in vitro chondrogenesis, limitations to alginate gels include low mechanical properties and slow degradation rate.

Agarose is a linear polysaccharide derived from Asian seaweeds that solidifies when cooled, and has been widely used to study chondrocyte response to deformational loading since it is able to transmit applied mechanical forces to cells during compression [139]. Chitosan is a biosynthetic polysaccharide derivative of chitin that is found in the exoskeletons of arthropods that is a liquid at room temperature and gels at physiological temperatures. It is a semicrystalline polymer that is biocompatible, degraded in vivo by lysozymes, and can interact with GFs and adhesion proteins. In addition, a number of methods have been used to ionically or covalently crosslink chitosan or chitosan derivatives, to improve mechanical properties [140, 141]. Chitosan and chitosan hybrid hydrogels support normal chondrocyte phenotypes in $2 \mathrm{D}$ $[140,141]$ and 3D cultures [142].

Some synthetic copolymers have also been investigated as thermoreversible hydrogels, with gelation occurring above their lower critical solution temperature (LCST). These include $p$ (NiPAAm-co-AAC) and poly(propylene fumarate-co-ethylene glycol) (p(PF-co-EG)), which are capable of retaining chondrocyte phenotype and viability $[143,144]$. Within these gels, cells remained responsive to co-encapsulated soluble factors like HA and TGF- $\beta 3$, which can lead to increased expression and synthesis of cartilage-specific ECM proteoglycans [145].

Self-assembling peptides constitute another class of biomaterials that can be made into hydrogels, and form by amino acid sequences of alternating ionic hydrophobic and uncharged hydrophilic side groups. These self- assembling peptide hydrogels form stable $\beta$-sheets of interwoven nanofibers when exposed to an electrolyte solution and are capable of rapidly encapsulating chondrocytes at physiological electrolyte concentrations and $\mathrm{pH}$ levels. RAD-, ELK-, and EAK-based peptides form strong $\beta$-sheet secondary structures in aqueous solutions [146]. For example, Zhang and coworkers have produced a stable self-assembling EAK16 membrane that does not dissolve by the addition of heat, acidic or alkaline solutions, or proteolytic enzymes [147]. This stability may be due to complementary ionic bonds between glutamic and lysine side chains. Kisiday et al showed that articular chondrocytes maintain their phenotype and produce cartilage-like ECM after 4 weeks when encapsulated in self-assembling peptide KLD-12 hydrogels in vitro [148] and respond to dynamic compression loading, with an increase in proteoglycan synthesis and mechanical properties over free-swelling controls 
[149]. In addition, synthetic self-assembling peptides can be modified to incorporate biologically active motifs that promote cell-matrix interactions [146].

\subsection{Sponges}

Sponges are porous scaffolds whose properties are dependent on pore size, porosity, and interconnectivity. Porosity dictates surface area [120] for cell adhesion, while pore size and interconnectivity affect cell infiltration and migration, matrix deposition and distribution [150], and nutrient and waste exchange. To date, several methods have been employed to manufacture sponges, including: porogen leaching, freeze-drying, and gas foaming. These manufacturing methods affect scaffold architecture, which in turn affects tissue formation, and can be used to encapsulate GFs [151]. To date, numerous materials have been used to fabricate sponge scaffolds, including poly ( $\alpha$-hydroxy esters) [152,153], alginate [154], polyglactin/ polydioxanone [155], chitosan [156-158], silk fibroin [76,77,159,160], HA [84,111], collagen [161] and gelatin $[84,158,162]$. A novel biodegradable elastomer scaffold from poly $(1,8$ octanediol citrate) (POC) has been fabricated by salt-leaching and supported the growth of chondrocytes in vitro [163]. This POC scaffold is capable of complete recovery from compressive deformation, and may provide good structural support in the mechanically loaded knee environment. In addition, resorbable polyglactin/polydioxanone scaffolds have been used in full thickness equine defects and showed good cartilage repair with integration into surrounding tissue [155].

Chitosan can also be formed into sponges via freeze-drying and lyophilization [157]. In a study by Kuo et al, chitosan and chitin hybridized scaffolds in various compositions were investigated as potential scaffolds [156]. An increase from 20 to $50 \mathrm{wt} \%$ of chitin resulted in smaller pore diameters, increased surface area, a higher Young's modulus, and lower extensibility, which resulted in increased cell numbers and ECM production in 28 days. Chitosan has also been hybridized with gelatin, which serves as a substrate for cell adhesion [158]. This chitosan/ gelatin scaffold was used for elastic cartilage repair and neocartilage exhibited type II collagen, elastic fibers, and GAG production, with total GAG content $~ 90 \%$ of that found in native auricular cartilage [158].

Silk fibroin is composed of a filament core protein called fibroin with a glue-like coat of sericin proteins. Sponges can be formed from silk fibroin by a solvent casting/salt leaching method that supports both chondrocytes [164] and stem cells [77]. Compared to fast degrading collagen scaffolds, silk scaffolds supported greater proliferation and chondrogenesis of MSCs [76, 159]. Collagen and collagen hybrid sponges have also been formed that support chondrocyte growth and phenotype retention [161]. The use of collagen microsponges in the porous openings of PLGA fibers [165] and sponges [153] has yielded new hybrid scaffolds with improved properties. Furthermore, type II collagen-GAG scaffolds with varying crosslinking densities can mediate cell behavior. In a study by Vickers et al, chondrocytes seeded on type II collagen-GAG scaffolds with low crosslinking densities experienced cell-mediated contraction, an increase in cell number, enhanced chondrogenesis, and increased degradation rates [161].

\subsection{Meshes}

Meshes are networks of woven and non-woven fibers, where variations in void volume and fiber diameter and directionality can dictate cell behavior. Non-woven meshes have high void volumes and surface areas that are well suited for tissue regeneration, whereas woven meshes exhibit greater strengths and can be made in a wide range of porosities. In general, these prefabricated forms can be cultured in vitro with cells to create mechanically stable scaffolds and then implanted in vivo for complete repair. A drawback to prefabricated scaffolds is a difficulty in filling irregularly shaped-defects, where incomplete contact with surrounding 
cartilage may hinder complete integration. 3D fiber deposition is one technique used to form scaffolds with regulated patterns [166]. Moroni et al were able to produce a scaffold with biomechanical properties comparable to bovine articular cartilage using 3D fiber deposition of poly(ethylene oxide) terephthalate/poly(butylene) terephthalate (PEOT/PBT) [167]. This group also adapted the method to develop a shell-core fiber architecture [168].

Recently, electrospinning has generated much interest to produce biomaterials with nano-scale polymer fibers that mimic collagen fibrils in cartilage ECM [169]. Fibers are generated as the surface charge of the polymer droplet overcomes its surface tension in an applied electric field, causing an instability that creates jets of polymer that can then be collected as solvent evaporates. Advantages to using electrospun scaffolds include high surface areas to volume ratios and fully interconnected pores, and the ability to create aligned fibers. By collecting the nanofibers on a rotating mandrel, aligned fibrous scaffolds can be fabricated, and can mimic the anisotropic morphology of some tissues. These nanofibrous scaffolds support chondrocytes and stem cells $[80,169]$.

The most commonly used meshes are made of poly( $\alpha$-hydroxy esters). These meshes have been used since the early 1990's for cartilage regeneration and include poly(lactic acid) (PLA), PGA, and their copolymers (PLGA). PGA is the most hydrophilic of this group and degrades into a natural metabolite that is completely resorbed through metabolic pathways. On the other hand, PLA, with an additional methyl group, is more hydrophobic, resulting in slower degradation. Copolymers of PLA and PGA can be optimized for mechanical and degradation properties. Shin et al showed that changes in copolymer composition resulted in differential degradation, where PLGA at a 50:50 composition degraded faster than 75:25 due to the higher PGA content [170]. Furthermore, polyester scaffolds can be modified with biological agents like type II collagen [171] and HA [172]. Immobilization of type II collagen on PLLA/PLGA scaffolds increased chondrocyte proliferation and GAG deposition while decreasing inflammatory responses by preventing host tissue infiltration and capsule formation [171]. Immobilization of HA to the surface of PLGA scaffolds enhanced chondrocyte attachment and substantially increased GAG and collagen synthesis [172]. Furthermore, MSCs seeded on PLGA scaffolds resulted in smooth, shiny white hyaline-like tissue after 12 weeks of in vivo culture in a rabbit defect [173]. PCL is another member of the poly( $\alpha$-hydroxy ester) family with slower degradation kinetics. Recently, PCL has been electrospun to form nanofibrous scaffolds capable of supporting proliferating chondrocytes that produce proteoglycan-rich matrices [169]. Furthermore, these scaffolds can also support chondrogenesis of MSCs comparable to cell pellet controls [80].

Several natural materials have also been processed as fibrous scaffolds, including cellulose [174] and HA derivatives [44,175-177]. Non-woven cellulose II fabrics coated with calcium phosphate supported better cell adhesion than unmodified fabrics, where calcium leaching from the scaffold has the potential to mimic the cartilage microenvironment in the vicinity of subchondral bone [174]. Non-woven HA esters (HYAFF(R) derivatives) are semisynthetic, resorbable meshes that support cell adhesion, proliferation, and production of cartilage-specific ECM in vitro $[44,175,176]$ and in vivo $[111,177]$. In a pilot study by Radice et al, HYAFF(R) 11 elicited no inflammatory response and completely degraded within 4 months of implantation [177]. In a clinical setting, Hyalograft ${ }^{\circledR} \mathrm{C}$ (a graft composed of autologous chondrocytes grown on a HYAFF(R) 11 scaffold) has been used to treat a number of human articular cartilage defects [178-180]. Hyalograft ${ }^{\circledR} \mathrm{C}$ repaired cartilage showed significant improvements over preoperation assessments with cartilage regeneration even in joints with progressed osteoarthritis [179]. 


\section{Stimulating Factors}

As the third component of the tissue engineering triad, stimulating factors have been employed to induce, accelerate, and/or enhance cartilage formation (Table 3). For instance, GFs and other additives may be added to culture media in vitro or incorporated into scaffolds for in vivo delivery to control cellular differentiation and tissue formation. In addition, gene therapy has emerged as another method of local delivery, where cells can be engineered to over-express bioactive molecules. An additional approach is the introduction of mechanical signals through loading regimes such as hydrostatic or dynamic pressure or through the use of bioreactors. Since many types of cartilage depend on mechanical forces to maintain healthy function, this approach has been used to alter cellular differentiation and tissue production.

\subsection{Growth Factors and Additives}

A number of growth factors like TGF- $\beta$, FGF, BMP, and IGF, along with other soluble factors like HA, chondroitin sulfate, and insulin, have been explored for their effects on cartilage tissue engineering. These factors have been investigated independently and synergistically, with outcomes dependent on cell type and culture conditions. Members of the TGF- $\beta$ family have been shown to play a major role in cartilage development. They are commonly used to induce chondrogenesis in embryonic [104] and adult MSCs [182,183], to increase cartilage ECM synthesis [184], and to enhance proliferation of chondrocytes [185,186]. Several studies have shown that TGF- $\beta$ isoforms differ in their effects on various cell types, where TGF- $\beta 1$ is responsible for initial cell-cell interactions between condensing progenitor cells [187], TGF$\beta 2$ mediates hypertrophic differentiation, and TGF- $\beta 3$ has stronger effects on MSC differentiation $[188,189]$. Another growth factor, IGF-1, acts in an anabolic manner to increase the production of proteoglycans and type II collagen [71,190].

FGF-2 is a mitogen involved in wound healing that has been used to preserve the chondrogenic potential of monolayer expanded chondrocytes [191,192] and to increase cell proliferation [192-194], which in turn can result in greater ECM deposition [195] and accelerated repair [196]. BMPs impact both chondrogenesis and osteogenesis, and are attractive for in vivo osteochondral defect studies as they can assist osteochondral integration at the implant site. These morphogens regulate chondrocyte differentiation states and ECM composition. Specifically, BMP-2 and -7 have been shown to increase matrix production in chondrocytes and progenitor cells. BMP-2 increases TIMP-1 [197], Sox 9 [68], type II collagen [68,198], and aggrecan [68] expression levels, while BMP-7 stimulates the production of proteoglycanrich ECM and suppresses fibroblast infiltration into the scaffold [199]. BMP-7 transfection into periosteal-derived MSCs resulted in complete or near complete bone and cartilage regeneration in an osteochondral rabbit defect model with a PGA scaffold after 8 weeks [200]. Furthermore, BMP-2 and -7 act synergistically, resulting in even better matrix production [198].

Methods to incorporate GFs and other soluble factors directly into scaffolds have been developed to improve cartilage formation. For delivery in vivo, these additives can be loaded in the scaffold itself and/or in microspheres or microparticles, which are then incorporated into the scaffold. Release profiles of these additives are dictated by degradation and diffusion properties. For in vivo applications, TGF- $\beta$ has been incorporated into hydrogels composed of oligo(poly(ethylene glycol) fumarate) (OPF) [201,202], PEODA [203], and fibrin [204], and/ or loaded into microspheres or microparticles, made of PLGA [205], gelatin [84,201], and chitosan $[184,206]$. Thus, growth factor release can be controlled by crosslinking density and/ or variations in the size of the microparticles. In general, the burst release of the GF is decreased when loaded microspheres are encapsulated within a scaffold $[201,205]$. Many in vitro studies have shown additive benefits of using TGF- $\beta$ and IGF-1 in combination [207]. However, Holland and colleagues showed that these in vitro results may not be as effective in an in 
vivo environment. In an osteochondral repair in rabbits, microparticle delivery of IGF-1 in OPF gels with articular chondrocytes showed significantly better repair overall over controls without IGF-1, yet this enhancement was not observed when delivered in combination with TGF- $\beta 1$ [208].

In addition, others have incorporated soluble HA to improve tissue quality. Scaffolds supplemented with soluble HA have improved cell proliferation [162], increased expression of cartilage-specific matrix proteins [209], and increased matrix synthesis [111,154,162,210]. Furthermore, for photopolymerization applications, HA increases the viscosity of the precursor solution, allowing for better retention of the solution at the injection site [203]. The addition of chondroitin sulfate has been shown to promote cell ingrowth and tissue formation [211], while chondroitinase $\mathrm{ABC}$ treatment has been shown to induce maturational growth and enhanced tensile integrity of cartilage explants [212].

\subsection{Gene Therapy}

Many biological agents have a short half life, which limits their in vivo efficacy. Gene therapy is an alternative approach to encapsulating bioactive molecules in scaffolds. Ex vivo gene therapy has drawn much interest as a method to transiently over-express and release proteins from cell-seeded scaffolds to provide local delivery [213]. Both viral (e.g. retroviruses and adenoviruses) and non-viral agents (polymers and liposomes) can be used to transfect cells. Viral vectors typically have higher transfection efficiencies but carry greater safety concerns, whereas non-viral vectors exhibit lower transfection efficiencies and carry fewer safety concerns. FuGene 6 is a non-viral vector that has been successfully used to transfect articular chondrocytes at an efficiency of 35\% with the transgene IGF-1 [214]. Encapsulation of these transfected cells in alginate spheres resulted in IGF-1 expression for up to 6 weeks. Transfection of BMSCs has also been accomplished within the scaffold, where porous chitosan/collagen scaffolds were created by freeze drying with TGF- $\beta 1$ plasmids [215]. Transfected scaffolds increased proliferation rates and the expression of type II collagen and aggrecan. Success has also been shown with PGA sponges, where periosteal-derived stem cells were tranduced $e x$ vivo with BMP-7, and showed improved healing of full thickness cartilage defects after only 6 weeks [216]. With gene therapy for cartilage regeneration in its infancy, much remains to be investigated, including endless combinations of modified cells and scaffolds.

\subsection{Hydrostatic Pressure}

In the joint cavity, cartilage exists in an environment of reduced oxygen and intermittent hydrostatic pressure. Thus, mimicking these conditions may provide a means to improve chondrogenesis in vitro. Low oxygen tension (5\%) has stimulated the proliferation and type II collagen expression [217], as well as increased cartilage-specific biosynthesis [24,218], of chondrocytes. Hydrostatic pressure applied within physiological levels has been beneficial [218-221]; however, the effects of loading are highly dependent on the loading regimen [217] and require much optimization. Chondrocytes loaded at $10 \mathrm{MPa}$ and $1 \mathrm{~Hz}$ for 4 hours/day, 5 days/week, for up to 8 weeks showed an increase in collagen production and prevention of GAG loss over static controls [221]. The benefits of hydrostatic loading were also noted in chondro-induced MSCs, where 0.1MPa of loading increased Sox 9 and aggrecan expression and 10MPa of loading generated a maximum response for type II collagen, while matrix condensation was observed with increasing hydrostatic pressure [219]. Hansen and colleagues reported that chondrocytes loaded at $0.2 \mathrm{MPa}$ and $0.1 \mathrm{~Hz}$ for $30 / 2$ or $2 / 30$ minutes of on/off loading showed inhibited proliferation and increased collagen secretion or increased proliferation and lowered collagen expression, respectively [218]. 


\subsection{Dynamic Compression}

There is significant evidence that dynamic compressive loading has a stimulatory effect on cartilage, chondrocytes, and stem cells. Chondrocytes exhibit compressibility and behavioral changes with compressive load as a function of strain. Numerous loading regimes ranging from a single application [222,223] to continuous loading [139,224-226] have been investigated as a means to accelerate and improve tissue formation. In each case, loading regimes must be optimized for cell type, seeding density, and scaffold. Recently $\mathrm{Ng}$ and colleagues attempted to engineer a stratified cartilage construct with layered $2 \%$ and $3 \%$ agarose with dynamic loading over 28 days. However, increased bulk mechanical and biochemical properties were only seen in the $2 \%$ gel [227]. In addition, chondrocytes encapsulated in fibrin glue were not affected by dynamic loading, even though loading has been shown to positively stimulated chondrocytes in agarose [228]

Studies have shown catabolic and anabolic effects of compressive loading, hinting at a structural remodeling effect of the newly synthesized matrix through loading [222]. A single application of a uniaxial compressive load $(1 \mathrm{kPa}, 1 \mathrm{~Hz}, 30 \mathrm{~min})$ increased collagen and proteoglycan synthesis and improved mechanical properties [223]. This single application of load transiently increased MMP-3 and MMP-13 expression, and produced a catabolic change 2 hours post-stimulation characterized by the release of proteoglycans and collagen into the culture media. This was followed by an anabolic change with an increase in type II collagen and aggrecan expression 12 hours post-stimulation, indicating that cyclic loading has a remodeling effect involving the mitogen-activated protein kinase (MAPK) pathway.

Furthermore, the addition of growth factors with loading appears to have a synergistic effect. Mauck et al showed that stimulatory responses could be increased with the addition of TGF$\beta 1$ and IGF, including increased proteoglycan and collagen contents and equilibrium aggregate modulus of chondrocytes cultured in agarose gels [207]. Furthermore, Chowdhury and colleagues showed that TGF- $\beta 3$ modulates cellular responses during dynamic loading via an integrin mediated mechanotransduction, where the addition of the peptide GRGDSP, a competitive ligand for $\alpha 5 \beta 1$ integrin binding, was able to reverse the compression-induced stimulation [229]. However, one problem encountered with dynamic loading is the loss of newly synthesized matrix proteins to the culture media [226].

\subsection{Bioreactors}

Bioreactors have been employed to accelerate and improve the growth of engineered cartilage in vitro. They serve to enhance nutrient transport and provide a hydrodynamic environment that imposes a fluid-induced shear stress to promote the synthesis of cartilage-specific matrix proteins. Dynamic cell seeding of porous scaffolds, typically done in spinner flasks, has led to faster adhesion and better cell distributions [112]. Though the effects are scaffold dependent, chondrocyte-laden scaffolds grown in perfusion culture increased cell proliferation and biochemical content compared to static culture [230,231]. For long-term in vitro culture, low shear stresses stimulate ECM synthesis and deposition, yielding greater tissue formation, while high shear stresses suppress GAG deposition. In general, higher seeding densities have enhanced GAG content, potentially due to cell-cell interactions [23,112], while scaffolds seeded at low cell densities fail to elicit a response in bioreactor culture [232]. Bioreactors currently being investigated for cartilage tissue engineering include: a parallel-plate bioreactor [233], rotating wall bioreactor [23], and a concentric cylinder bioreactor [234]. Recently, a newly developed wavy-wall bioreactor (WWB) has been shown to increase chondrocyte proliferation and ECM deposition on PGA scaffolds over the common spinner flask culture [235]. Compared to a spinner flask, the novel bioreactor reduces fluid shear stresses and increases axial mixing. The addition of growth factors, like IGF-1, can also be used in combination with bioreactors to further enhance matrix accumulation [190]. 


\section{Conclusions}

Cell source, scaffolds, and signaling factors make up the tissue engineering triad. One of the biggest challenges for cartilage tissue engineering is cell source. Current work on alternatives to chondrocytes is expanding, and the potential and limitations of fibroblasts and stem cells are being explored. Novel biomaterials are being continuously developed and are leading to unique interactions with cells through controlled biomaterial chemistry, structure, and the addition of biological molecules. Also, the incorporation of stimulatory factors such as bioactive molecules, gene therapy, mechanical loading, and bioreactors are leading to enhanced cartilage production. Ultimately, clinical translation and feasibility needs to be considered with all of these approaches if a successful tissue engineered cartilage product is to make it through the regulatory process and into patients.

\section{Acknowledgements}

We would like to acknowledge funding from the NIH (K22DE015761) and an NSF Graduate Research Fellowship (to $\mathrm{CC}$ ).

\section{References}

1. Langer RS, Vacanti JP. Tissue engineering: The challenges ahead. Scientific American 1999;280:8689. [PubMed: 10201120]

2. Marlovits S, Zeller P, Singer P, Resinger C, Vecsei V. Cartilage repair: generations of autologous chondrocyte transplantation. Eur J Radiol 2006;57:24-31. [PubMed: 16188417]

3. Elisseeff J. Injectable cartilage tissue engineering. Expert Opin Biol Ther 2004;4:1849-1859. [PubMed: 15571448]

4. Nicoll SB, Wedrychowska A, Smith NR, Bhatnagar RS. Modulation of proteoglycan and collagen profiles in human dermal fibroblasts by high density micromass culture and treatment with lactic acid suggests change to a chondrogenic phenotype. Connect Tissue Res 2001;42:59-69. [PubMed: 11696989]

5. Goessler UR, Bugert P, Bieback K, Baisch A, Sadick H, Verse T, Kluter H, Hormann K, Riedel F. Expression of collagen and fiber-associated proteins in human septal cartilage during in vitro dedifferentiation. International Journal of Molecular Medicine 2004;14:1015-1022. [PubMed: 15547667]

6. Goessler UR, Bugert P, Bieback K, Sadick H, Baisch A, Hormann K, Riedel F. In vitro analysis of differential expression of collagens, integrins, and growth factors in cultured human chondrocytes. Otolaryngology-Head and Neck Surgery 2006;134:510-515. [PubMed: 16500455]

7. Goessler UR, Bieback K, Bugert P, Heller T, Sadick H, Hormann K, Riedel F. In vitro analysis of integrin expression during chondrogenic differentiation of mesenchymal stem cells and chondrocytes upon dedifferentiation in cell culture. International Journal of Molecular Medicine 2006;17:301-307. [PubMed: 16391830]

8. Goessler UR, Bugert P, Bieback K, Deml M, Sadick H, Hormann K, Riedel F. In-vitro analysis of the expression of TGF beta-superfamily-members during chondrogenic differentiation of mesenchymal stem cells and chondrocytes during dedifferentiation in cell culture. Cellular \& Molecular Biology Letters 2005;10:345-362. [PubMed: 16010298]

9. Goessler UR, Bieback K, Bugert P, Naim R, Schafer C, Sadick H, Hormann K, Riedel F. Human chondrocytes differentially express matrix modulators during in vitro expansion for tissue engineering. International Journal of Molecular Medicine 2005;16:509-515. [PubMed: 16142380]

10. Schulze-Tanzil G, Mobasheri A, de Souza P, John T, Shakibaei M. Loss of chondrogenic potential in dedifferentiated chondrocytes correlates with deficient Shc-Erk interaction and apoptosis. Osteoarthritis and Cartilage 2004;12:448-458. [PubMed: 15135141]

11. Darling EM, Athanasiou KA. Rapid phenotypic changes in passaged articular chondrocyte subpopulations. Journal of Orthopaedic Research 2005;23:425-432. [PubMed: 15734258] 
12. Chung C, Mesa J, Miller GJ, Randolph MA, Gill TJ, Burdick JA. Effects of auricular chondrocyte expansion on neocartilage formation in photocrosslinked hyaluronic acid networks. Tissue Engineering 2006;12:2665-2673. [PubMed: 16995800]

13. Barbero A, Grogan SP, Mainil-Varlet P, Martin I. Expansion on specific substrates regulates the phenotype and differentiation capacity of human articular chondrocytes. Journal of Cellular Biochemistry 2006;98:1140-1149. [PubMed: 16514667]

14. Brodkin KR, Garcia AJ, Levenston ME. Chondrocyte phenotypes on different extracellular matrix monolayers. Biomaterials 2004;25:5929-5938. [PubMed: 15183607]

15. Darling EM, Athanasiou KA. Retaining zonal chondrocyte phenotype by means of novel growth environments. Tissue Engineering 2005;11:395-403. [PubMed: 15871669]

16. Martin I, Vunjak-Novakovic G, Yang J, Langer R, Freed LE. Mammalian chondrocytes expanded in the presence of fibroblast growth factor 2 maintain the ability to differentiate and regenerate threedimensional cartilaginous tissue. Experimental Cell Research 1999;253:681-688. [PubMed: 10585291]

17. Buschmann MD, Gluzband YA, Grodzinsky AJ, Kimura JH, Hunziker EB. Chondrocytes in agarose culture synthesize a mechanically functional extracellular matrix. J Orthop Res 1992;10:745-758. [PubMed: 1403287]

18. Homicz MR, Chia SH, Schumacher BL, Masuda K, Thonar EJ, Sah RL, Watson D. Human septal chondrocyte redifferentiation in alginate, polyglycolic acid scaffold, and monolayer culture. Laryngoscope 2003;113:25-32. [PubMed: 12514377]

19. Lin Z, Willers C, Xu JA, Zheng MH. The chondrocyte: Biology and clinical application. Tissue Engineering 2006;12:1971-1984. [PubMed: 16889526]

20. An YH, Webb D, Gutowska A, Mironov VA, Friedman RJ. Regaining chondrocyte phenotype in thermosensitive gel culture. Anat Rec 2001;263:336-341. [PubMed: 11500809]

21. Malda J, Kreijveld E, Temenoff JS, van Blitterswijk CA, Riesle J. Expansion of human nasal chondrocytes on macroporous microcarriers enhances redifferentiation. Biomaterials 2003;24:51535161. [PubMed: 14568432]

22. Malda J, Van Blitterswijk CA, Grojec M, Martens DE, Tramper J, Riesle J. Expansion of bovine chondrocytes on microcarriers enhances redifferentiation. Tissue Engineering 2003;9:939-948. [PubMed: 14633378]

23. Freed LE, Hollander AP, Martin I, Barry JR, Langer R, Vunjak-Novakovic G. Chondrogenesis in a cell-polymer-bioreactor system. Experimental Cell Research 1998;240:58-65. [PubMed: 9570921]

24. Kurz B, Domm C, Jin MS, Sellckau R, Schunke M. Tissue engineering of articular cartilage under the influence of collagen I/III membranes and low oxygen tension. Tissue Engineering 2004;10:1277-1286. [PubMed: 15363182]

25. Mandl EW, van der Veen SW, Verhaar JAN, van Osch GJVM. Serum-free medium supplemented with high-concentration FGF2 for cell expansion culture of human ear chondrocytes promotes redifferentiation capacity. Tissue Engineering 2002;8:573-580. [PubMed: 12201997]

26. Gan L, Kandel RA. In vitro cartilage tissue formation by co-culture of primary and passaged chondrocytes. Tissue Engineering 2007;13:831-842. [PubMed: 17253927]

27. Woodfield TBF, Miot S, Martin I, van Blitterswijk CA, Riesle J. The regulation of expanded human nasal chondrocyte re-differentiation capacity by substrate composition and gas plasma surface modification. Biomaterials 2006;27:1043-1053. [PubMed: 16125219]

28. Kim HT, Zaffagnini S, Mizuno S, Abelow S, Safran MR. A peek into the possible future of management of articular cartilage injuries: Gene therapy and scaffolds for cartilage repair. Journal of Orthopaedic \& Sports Physical Therapy 2006;36:765-773. [PubMed: 17063838]

29. Darling EM, Hu JCY, Athanasiou KA. Zonal and topographical differences in articular cartilage gene expression. Journal of Orthopaedic Research 2004;22:1182-1187. [PubMed: 15475195]

30. Hidaka C, Cheng C, Alexandre D, Bhargava M, Torzilli PA. Maturational differences in superficial and deep zone articular chondrocytes. Cell and Tissue Research 2006;323:127-135. [PubMed: 16133144]

31. Klein TJ, Chaudhry M, Bae WC, Sah RL. Depth-dependent biomechanical and biochemical properties of fetal, newborn, and tissue-engineered articular cartilage. Journal of Biomechanics 2007;40:182190. [PubMed: 16387310] 
32. Klein TJ, Schumacher BL, Schmidt TA, Li KW, Voegtline MS, Masuda K, Thonar EJMA, Sah RL. Tissue engineering of stratified articular cartilage from chondrocyte subpopulations. Osteoarthritis and Cartilage 2003;11:595-602. [PubMed: 12880582]

33. Sharma B, Williams CG, Kim TK, Sun DN, Malik A, Khan M, Leong K, Elisseeff JH. Designing zonal organization into tissue-engineered cartilage. Tissue Engineering 2007;13:405-414. [PubMed: 17504064]

34. Kim TK, Sharma B, Williams CG, Ruffner MA, Malik A, McFarland EG, Elisseeff JH. Experimental model for cartilage tissue engineering to regenerate the zonal organization of articular cartilage. Osteoarthritis and Cartilage 2003;11:653-664. [PubMed: 12954236]

35. Woodfield TBF, Van Blitterswijk CA, De Wijn J, Sims TJ, Hollander AP, Riesle J. Polymer scaffolds fabricated with pore-size gradients as a model for studying the zonal organization within tissueengineered cartilage constructs. Tissue Engineering 2005;11:1297-1311. [PubMed: 16259586]

36. van Osch GJVM, Mandl EW, Jahr H, Koevoet W, Nolst-Trenite G, Verhaar JA. Considerations on the use of ear chondrocytes as donor chondrocytes for cartilage tissue engineering. Biorheology 2004;41:411-421. [PubMed: 15299273]

37. Panossian A, Ashiku S, Kirchhoff CH, Randolph MA, Yaremchuk MJ. Effects of cell concentration and growth period on articular and ear chondrocyte transplants for tissue engineering. Plastic and Reconstructive Surgery 2001;108:392-402. [PubMed: 11496181]

38. Kafienah W, Jakob M, Demarteau O, Frazer A, Barker MD, Martin I, Hollander AP. Threedimensional tissue engineering of hyaline cartilage: Comparison of adult nasal and articular chondrocytes. Tissue Engineering 2002;8:817-826. [PubMed: 12459060]

39. Hicks DL, Sage AB, Schumacher BL, Sah RL, Watson D. Growth and phenotype of low-density nasal septal chondrocyte monolayers. Otolaryngology-Head and Neck Surgery 2005;133:417-422. [PubMed: 16143193]

40. Naumann A, Dennis JE, Aigner J, Coticchia J, Arnold J, Berghaus A, Kastenbauer ER, Caplan AI. Tissue engineering of autologous cartilage grafts in three-dimensional in vitro macroaggregate culture system. Tissue Engineering 2004;10:1695-1706. [PubMed: 15684678]

41. Shikani AH, Fink DJ, Sohrabi A, Phan P, Polotsky A, Hungerford DS, Frondoza CG. Propagation of human nasal chondrocytes in microcarrier spinner culture. American Journal of Rhinology 2004;18:105-112. [PubMed: 15152876]

42. Miot S, Woodfield T, Daniels AU, Suetterlin R, Peterschmitt I, Heberer M, van Blitterswijk CA, Riesle J, Martin I. Effects of scaffold composition and architecture on human nasal chondrocyte redifferentiation and cartilaginous matrix deposition. Biomaterials 2005;26:2479-2489. [PubMed: 15585250]

43. Vinatier C, Magne D, Moreau A, Gauthier O, Malard O, Vignes-Colombeix C, Daculsi G, Weiss P, Guicheux J. Engineering cartilage with human nasal chondrocytes and a silanized hydroxypropyl methylcellulose hydrogel. Journal of Biomedical Materials Research Part A 2007;80A:66-74. [PubMed: 16958048]

44. Aigner J, Tegeler J, Hutzler P, Campoccia D, Pavesio A, Hammer C, Kastenbauer E, Naumann A. Cartilage tissue engineering with novel nonwoven structured biomaterial based on hyaluronic acid benzyl ester. Journal of Biomedical Materials Research 1998;42:172-181. [PubMed: 9773813]

45. Richmon JD, Sage AB, Shelton E, Schumacher BL, Sah RL, Watson D. Effect of growth factors on cell proliferation, matrix deposition, and morphology of human nasal septal chondrocytes cultured in monolayer. Laryngoscope 2005;115:1553-1560. [PubMed: 16148694]

46. van Osch GJVM, Marijnissen WJCM, van der Veen SW, Verwoerd-Verhoef HL. The potency of culture-expanded nasal septum chondrocytes for tissue engineering of cartilage. American Journal of Rhinology 2001;15:187-192. [PubMed: 11453506]

47. Isogai N, Kusuhara H, Ikada Y, Ohtani H, Jacquet R, Hillyer J, Lowder E, Landis WJ. Comparison of different chondrocytes for use in tissue engineering of cartilage model structures. Tissue Engineering 2006;12:691-703. [PubMed: 16674284]

48. Tay AG, Farhadi J, Suetterlin R, Pierer G, Heberer M, Martin I. Cell yield, proliferation, and postexpansion differentiation capacity of human ear, nasal, and rib chondrocytes. Tissue Engineering 2004;10:762-770. [PubMed: 15265293] 
49. Johnson TS, Xu JW, Zaporojan VV, Mesa JM, Weinand C, Randolph MA, Bonassar LJ, Winograd JM, Yaremchuk MJ. Integrative repair of cartilage with articular and nonarticular chondrocytes. Tissue Eng 2004;10:1308-1315. [PubMed: 15588391]

50. Barbero A, Grogan S, Schafer D, Heberer M, Mainil-Varlet P, Martin I. Age related changes in human articular chondrocyte yield, proliferation and post-expansion chondrogenic capacity. Osteoarthritis and Cartilage 2004;12:476-484. [PubMed: 15135144]

51. Giannoni P, Pagano A, Maggi E, Arbico R, Randazzo N, Grandizio M, Cancedda R, Dozin B. Autologous chondrocyte implantation (ACI) for aged patients: development of the proper cell expansion conditions for possible therapeutic applications. Osteoarthritis and Cartilage 2005; 13:589600. [PubMed: 15979011]

52. Terada S, Fuchs JR, Yoshimoto H, Fauza DO, Vacanti JP. In vitro cartilage regeneration from proliferated adult elastic chondrocytes. Annals of Plastic Surgery 2005;55:196-201. [PubMed: 16034253]

53. Tran-Khanh N, Hoemann CD, McKee MD, Henderson JE, Buschmann MD. Aged bovine chondrocytes display a diminished capacity to produce a collagen-rich, mechanically functional cartilage extracellular matrix. Journal of Orthopaedic Research 2005;23:1354-1362. [PubMed: 16048738]

54. Mesa JM, Zaporojan V, Weinand C, Johnson TS, Bonassar L, Randolph MA, Yaremchuk MJ, Butler PE. Tissue engineering cartilage with aged articular chondrocytes in vivo. Plastic and Reconstructive Surgery 2006;118:41-49. [PubMed: 16816672]

55. Marlovits S, Tichy B, Truppe M, Gruber D, Schlegel W. Collagen expression in tissue engineered cartilage of aged human articular chondrocytes in a rotating bioreactor. International Journal of Artificial Organs 2003;26:319-330. [PubMed: 12757031]

56. Wenger R, Hans MG, Welter JF, Solchaga LA, Sheu YR, Malemud CJ. Hydrostatic pressure increases apoptosis in cartilage-constructs produced from human osteoarthritic chondrocytes. Frontiers in Bioscience 2006;11:1690-1695. [PubMed: 16368547]

57. Li Y, Tew SR, Russell AM, Gonzalez KR, Hardingham TE, Hawkins RE. Transduction of passaged human articular chondrocytes with adenoviral, retroviral, and lentiviral vectors and the effects of enhanced expression of SOX9. Tissue Engineering 2004;10:575-584. [PubMed: 15165474]

58. Gorti GK, Lo J, Falsafi S, Kosek J, Quan SY, Khuu DT, Koch RJ. Cartilage tissue engineering using cryogenic chondrocytes. Archives of Otolaryngology-Head \& Neck Surgery 2003;129:889-893. [PubMed: 12925350]

59. Yan H, Yu C. Repair of full-thickness cartilage defects with cells of different origin in a rabbit model. Arthroscopy 2007;23:178-187. [PubMed: 17276226]

60. French MM, Rose S, Canseco J, Athanasiou KA. Chondrogenic differentiation of adult dermal fibroblasts. Annals of Biomedical Engineering 2004;32:50-56. [PubMed: 14964721]

61. Yates KE, Forbes RL, Glowacki J. New chondrocyte genes discovered by representational difference analysis of chondroinduced human fibroblasts. Cells Tissues Organs 2004;176:41-53. [PubMed: 14745234]

62. Lee KH, Song SU, Hwang TS, Yi Y, Oh IS, Lee JY, Choi KB, Choi MS, Kim SJ. Regeneration of hyaline cartilage by cell-mediated gene therapy using transforming growth factor beta 1-producing fibroblasts. Hum Gene Ther 2001;12:1805-1813. [PubMed: 11560773]

63. Deng Y, Hu JC, Athanasiou KA. Isolation and chondroinduction of a dermis-isolated, aggrecansensitive subpopulation with high chondrogenic potential. Arthritis and Rheumatism 2007;56:168176. [PubMed: 17195219]

64. Johnstone B, Hering TM, Caplan AI, Goldberg VM, Yoo JU. In vitro chondrogenesis of bone marrowderived mesenchymal progenitor cells. Exp Cell Res 1998;238:265-272. [PubMed: 9457080]

65. Zuk PA, Zhu M, Mizuno H, Huang J, Futrell JW, Katz AJ, Benhaim P, Lorenz HP, Hedrick MH. Multilineage cells from human adipose tissue: implications for cell-based therapies. Tissue Eng 2001;7:211-228. [PubMed: 11304456]

66. Nawata M, Wakitani S, Nakaya H, Tanigami A, Seki T, Nakamura Y, Saito N, Sano K, Hidaka E, Takaoka K. Use of bone morphogenetic protein 2 and diffusion chambers to engineer cartilage tissue for the repair of defects in articular cartilage. Arthritis and Rheumatism 2005;52:155-163. [PubMed: 15641068] 
67. Adachi N, Sato K, Usas A, Fu FH, Ochi M, Han CW, Niyibizi C, Huard J. Muscle derived, cell based ex vivo gene therapy for treatment of full thickness articular cartilage defects. Journal of Rheumatology 2002;29:1920-1930. [PubMed: 12233887]

68. Park Y, Sugimoto M, Watrin A, Chiquet M, Hunziker EB. BMP-2 induces the expression of chondrocyte-specific genes in bovine synovium-derived progenitor cells cultured in threedimensional alginate hydrogel. Osteoarthritis and Cartilage 2005;13:527-536. [PubMed: 15922187]

69. Sakaguchi Y, Sekiya I, Yagishita K, Muneta T. Comparison of human stem cells derived from various mesenchymal tissues: superiority of synovium as a cell source. Arthritis Rheum 2005;52:2521-2529. [PubMed: 16052568]

70. Yokoyama A, Sekiya I, Miyazaki K, Ichinose S, Hata Y, Muneta T. In vitro cartilage formation of composites of synovium-derived mesenchymal stem cells with collagen gel. Cell and Tissue Research 2005;322:289-298. [PubMed: 16001268]

71. Fukumoto T, Sperling JW, Sanyal A, Fitzsimmons JS, Reinholz GG, Conover CA, O’Driscoll SW. Combined effects of insulin-like growth factor- 1 and transforming growth factor-beta1 on periosteal mesenchymal cells during chondrogenesis in vitro. Osteoarthritis Cartilage 2003;11:55-64. [PubMed: 12505488]

72. Coleman RM, Case ND, Guldberg RE. Hydrogel effects on bone marrow stromal cell response to chondrogenic growth factors. Biomaterials 2007;28:2077-2086. [PubMed: 17257670]

73. Huang CYC, Reuben PM, D'Ippolito G, Schiller PC, Cheung HS. Chondrogenesis of human bone marrow-derived mesenchymal stem cells in agarose culture. Anatomical Record Part a-Discoveries in Molecular Cellular and Evolutionary Biology 2004;278A:428-436.

74. Williams CG, Kim TK, Taboas A, Malik A, Manson P, Elisseeff J. In vitro chondrogenesis of bone marrow-derived mesenchymal stem cells in a photopolymerizing hydrogel. Tissue Engineering 2003;9:679-688. [PubMed: 13678446]

75. Pang YG, Cui PC, Chen WX, Gao PF, Zhang HZ. Quantitative study of tissue-engineered cartilage with human bone marrow mesenchymal stem cells. Archives of Facial Plastic Surgery 2005;7:7-11. [PubMed: 15655167]

76. Meinel L, Hofmann S, Karageorgiou V, Zichner L, Langer R, Kaplan D, Vunjak-Novakovic G. Engineering cartilage-like tissue using human mesenchymal stem cells and silk protein scaffolds. Biotechnology and Bioengineering 2004;88:379-391. [PubMed: 15486944]

77. Wang YZ, Kim UJ, Blasioli DJ, Kim HJ, Kaplan DL. In vitro cartilage tissue engineering with 3D porous aqueous-derived silk scaffolds and mesenchymal stem cells. Biomaterials 2005;26:70827094. [PubMed: 15985292]

78. Chen GP, Liu DC, Tadokoro M, Hirochika R, Ohgushi H, Tanaka J, Tateishi T. Chondrogenic differentiation of human mesenchymal stem cells cultured in a cobweb-like biodegradable scaffold. Biochemical and Biophysical Research Communications 2004;322:50-55. [PubMed: 15313172]

79. Fan HB, Hu YY, Zhang CL, Li XS, Lv R, Qin L, Zhu R. Cartilage regeneration using mesenchymal stem cells and a PLGA-gelatin/chondroitin/hyaluronate hybrid scaffold. Biomaterials 2006;27:45734580. [PubMed: 16720040]

80. Li WJ, Tuli R, Okafor C, Derfoul A, Danielson KG, Hall DJ, Tuan RS. A three-dimensional nanofibrous scaffold for cartilage tissue engineering using human mesenchymal stem cells. Biomaterials 2005;26:599-609. [PubMed: 15282138]

81. Indrawattana N, Chen GP, Tadokoro M, Shann LH, Ohgushi H, Tateishi T, Tanaka J, Bunyaratvej A. Growth factor combination for chondrogenic induction from human mesenchymal stem cell. Biochemical and Biophysical Research Communications 2004;320:914-919. [PubMed: 15240135]

82. Chen JW, Wang CY, Lu SH, Wu JZ, Guo XM, Duan CM, Dong LZ, Song Y, Zhang JC, Jing DY, Wu LB, Ding JD, Li DX. In vivo chondrogenesis of adult bone-marrow-derived autologous mesenchymal stem cells. Cell and Tissue Research 2005;319:429-438. [PubMed: 15672263]

83. Park KS, Jin CM, Kim SH, Rhee JM, Khang G, Han CW, Yang YS, Kim MS, Lee HB. Chondrogenic differentiation of bone marrow stromal cells in transforming growth factor-beta(1) loaded alginate bead. Macromolecular Research 2005;13:285-292.

84. Fan HB, Hu YY, Qin L, Li XS, Wu H, Lv R. Porous gelatin-chondroitin-hyaluronate tri-copolymer scaffold containing microspheres loaded with TGF-beta 1 induces differentiation of mesenchymal 
stem cells in vivo for enhancing cartilage repair. Journal of Biomedical Materials Research Part A 2006;77A:785-794. [PubMed: 16575912]

85. Guo XM, Wang CY, Zhang YF, Xia RY, Hu M, Duan CM, Zhao Q, Dong LZ, Lu JX, Song YQ. Repair of large articular cartilage defects with implants of autologous mesenchymal stem cells seeded into beta-tricalcium phosphate in a sheep model. Tissue Engineering 2004;10:1818-1829. [PubMed: 15684690]

86. Kayakabe M, Tsutsumi S, Watanabe H, Kato Y, Takagishi K. Transplantation of autologous rabbit BM-derived mesenchymal stromal cells embedded in hyaluronic acid gel sponge into osteochondral defects of the knee. Cytotherapy 2006;8:343-353. [PubMed: 16923610]

87. Tatebe M, Nakamura R, Kagami H, Okada K, Ueda M. Differentiation of transplanted mesenchymal stem cells in a large osteochondral defect in rabbit. Cytotherapy 2005;7:520-530. [PubMed: 16306014]

88. Akaogi H, Akimoto T, Miyaki S, Ushida T, Ochiai N, Tateishi T, Tanaka J. Basic fibroblast growth factor supports in vitro chondrogenesis of bone marrow-derived mesenchymal stem cells from patients with osteoarthritis. Materials Science \& Engineering C-Biomimetic and Supramolecular Systems 2004;24:403-406.

89. Tsuchiya K, Chen GP, Ushida T, Matsuno T, Tateishi T. The effect of coculture of chondrocytes with mesenchymal stem cells on their cartilaginous phenotype in vitro. Materials Science \& Engineering C-Biomimetic and Supramolecular Systems 2004;24:391-396.

90. Zhou GD, Liu W, Cui L, Cao YL. In vivo chondrogenesis of BMSCs at non-chondrogenesis site by co-transplantation of BMSCs and chondrocytes with pluronic as biomaterial. Asbm6: Advanced Biomaterials Vi 2005;288-289:3-6.

91. Mauck RL, Yuan X, Tuan RS. Chondrogenic differentiation and functional maturation of bovine mesenchymal stem cells in long-term agarose culture. Osteoarthritis and Cartilage 2006;14:179-189. [PubMed: 16257243]

92. Zuk PA, Zhu M, Ashjian P, De Ugarte DA, Huang JI, Mizuno H, Alfonso ZC, Fraser JK, Benhaim $\mathrm{P}$, Hedrick MH. Human adipose tissue is a source of multipotent stem cells. Mol Biol Cell 2002;13:4279-4295. [PubMed: 12475952]

93. Huang JI, Zuk PA, Jones NF, Zhu M, Lorenz HP, Hedrick MH, Benhaim P. Chondrogenic potential of multipotential cells from human adipose tissue. Plastic and Reconstructive Surgery 2004;113:585594. [PubMed: 14758221]

94. Chiou M, Xu Y, Longaker MT. Mitogenic and chondrogenic effects of fibroblast growth factor-2 in adipose-derived mesenchymal cells. Biochemical and Biophysical Research Communications 2006;343:644-652. [PubMed: 16554022]

95. Awad HA, Wickham MQ, Leddy HA, Gimble JM, Guilak F. Chondrogenic differentiation of adiposederived adult stem cells in agarose, alginate, and gelatin scaffolds. Biomaterials 2004;25:3211-3222. [PubMed: 14980416]

96. Erickson GR, Gimble JM, Franklin DM, Rice HE, Awad H, Guilak F. Chondrogenic potential of adipose tissue-derived stromal cells in vitro and in vivo. Biochemical and Biophysical Research Communications 2002;290:763-769. [PubMed: 11785965]

97. Lin YF, Luo E, Chen XZ, Liu L, Qiao J, Yan ZB, Li ZY, Tang W, Zheng XH, Tian WD. Molecular and cellular characterization during chondrogenic differentiation of adipose tissue-derived stromal cells in vitro and cartilage formation in vivo. Journal of Cellular and Molecular Medicine 2005;9:929_ 939. [PubMed: 16364200]

98. Masuoka K, Asazuma T, Hattori H, Yoshihara Y, Sato M, Matsumra K, Matsui T, Takase B, Nemoto $\mathrm{K}$, Ishihara M. Tissue engineering of articular cartilage with autologous cultured adipose tissuederived stromal cells using atelocollagen honeycomb-shaped scaffold with a membrane sealing in rabbits. Journal of Biomedical Materials Research Part B-Applied Biomaterials 2006;79B:25-34.

99. Betre H, Ong SR, Guilak F, Chilkoti A, Fermor B, Setton LA. Chondrocytic differentiation of human adipose-derived adult stem cells in elastin-like polypeptide. Biomaterials 2006;27:91-99. [PubMed: 16023192]

100. Estes BT, Wu AW, Guilak F. Potent induction of chondrocytic differentiation of human adiposederived adult stem cells by bone morphogenetic protein 6. Arthritis Rheum 2006;54:1222-1232. [PubMed: 16572454] 
101. Huang JI, Kazmi N, Durbhakula MM, Hering TM, Yoo JU, Johnstone B. Chondrogenic potential of progenitor cells derived from human bone marrow and adipose tissue: a patient-matched comparison. J Orthop Res 2005;23:1383-1389. [PubMed: 15936917]

102. Im GI, Shin YW, Lee KB. Do adipose tissue-derived mesenchymal stem cells have the same osteogenic and chondrogenic potential as bone marrow-derived cells? Osteoarthritis Cartilage 2005;13:845-853. [PubMed: 16129630]

103. Winter A, Breit S, Parsch D, Benz K, Steck E, Hauner H, Weber RM, Ewerbeck V, Richter W. Cartilage-like gene expression in differentiated human stem cell spheroids: a comparison of bone marrow-derived and adipose tissue-derived stromal cells. Arthritis Rheum 2003;48:418-429. [PubMed: 12571852]

104. Hwang NS, Kim MS, Sampattavanich S, Baek JH, Zhang ZJ, Elisseeff J. Effects of three-dimensional culture and growth factors on the chondrogenic differentiation of murine embryonic stem cells. Stem Cells 2006;24:284-291. [PubMed: 16109760]

105. Hwang NS, Varghese S, Zhang Z, Elisseeff J. Chondrogenic differentiation of human embryonic stem cell-derived cells in arginine-glycine-aspartate modified hydrogels. Tissue Engineering 2006;12:2695-2706. [PubMed: 16995803]

106. Kramer J, Hegert C, Guan K, Wobus AM, Muller PK, Rohwedel J. Embryonic stem cell-derived chondrogenic differentiation in vitro: activation by BMP-2 and BMP-4. Mech Dev 2000;92:193205. [PubMed: 10727858]

107. Kramer J, Hegert C, Hargus G, Rohwedel J. Mouse ES cell lines show a variable degree of chondrogenic differentiation in vitro. Cell Biol Int 2005;29:139-146. [PubMed: 15774311]

108. Toh WS, Yang Z, Liu H, Heng BC, Lee EH, Cao T. Effects of culture conditions and bone morphogenetic protein 2 on extent of chondrogenesis from human embryonic stem cells. Stem Cells 2007;25:950-960. [PubMed: 17218402]

109. Vats A, Bielby RC, Tolley N, Dickinson SC, Boccaccini AR, Hollander AP, Bishop AE, Polak JM. Chondrogenic differentiation of human embryonic stem cells: the effect of the micro-environment. Tissue Eng 2006;12:1687-1697. [PubMed: 16846363]

110. Bryant SJ, Anseth KS. Controlling the spatial distribution of ECM components in degradable PEG hydrogels for tissue engineering cartilage. Journal of Biomedical Materials Research Part A 2003;64A:70-79. [PubMed: 12483698]

111. Solchaga LA, Temenoff JS, Gao JZ, Mikos AG, Caplan AI, Goldberg VM. Repair of osteochondral defects with hyaluronan- and polyester-based scaffolds. Osteoarthritis and Cartilage 2005;13:297309. [PubMed: 15780643]

112. Freed LE, Marquis JC, Vunjaknovakovic G, Emmanual J, Langer R. Composition of Cell-Polymer Cartilage Implants. Biotechnology and Bioengineering 1994;43:605-614.

113. Iwasa J, Ochi M, Uchio Y, Katsube K, Adachi N, Kawasaki K. Effects of cell density on proliferation and matrix synthesis of chondrocytes embedded in atelocollagen gel. Artificial Organs 2003;27:249-255. [PubMed: 12662211]

114. Bryant SJ, Anseth KS. Hydrogel properties influence ECM production by chondrocytes photoencapsulated in poly(ethylene glycol) hydrogels. Journal of Biomedical Materials Research 2002;59:63-72. [PubMed: 11745538]

115. Bryant SJ, Anseth KS. The effects of scaffold thickness on tissue engineered cartilage in photocrosslinked poly(ethylene oxide) hydrogels. Biomaterials 2001;22:619-626. [PubMed: 11219727]

116. Bryant SJ, Nuttelman CR, Anseth KS. Cytocompatibility of UV and visible light photoinitiating systems on cultured NIH/3T3 fibroblasts in vitro. J Biomater Sci Polym Ed 2000;11:439-457. [PubMed: 10896041]

117. Bryant SJ, Durand KL, Anseth KS. Manipulations in hydrogel chemistry control photoencapsulated chondrocyte behavior and their extracellular matrix production. Journal of Biomedical Materials Research Part A 2003;67A:1430-1436. [PubMed: 14624532]

118. Rice MA, Anseth KS. Encapsulating chondrocytes in copolymer gels: Bimodal degradation kinetics influence cell phenotype and extracellular matrix development. Journal of Biomedical Materials Research Part A 2004;70A:560-568. [PubMed: 15307160] 
119. Lee HJ, Lee JS, Chansakul T, Yu C, Elisseeff JH, Yu SM. Collagen mimetic peptide-conjugated photopolymerizable PEG hydrogel. Biomaterials 2006;27:5268-5276. [PubMed: 16797067]

120. Sontjens SHM, Nettles DL, Carnahan MA, Setton LA, Grinstaff MW. Biodendrimer-based hydrogel scaffolds for cartilage tissue repair. Biomacromolecules 2006;7:310-316. [PubMed: 16398530]

121. Chen WY, Abatangelo G. Functions of hyaluronan in wound repair. Wound Repair Regen 1999;7:79-89. [PubMed: 10231509]

122. Nettles DL, Vail TP, Morgan MT, Grinstaff MW, Setton LA. Photocrosslinkable hyaluronan as a scaffold for articular cartilage repair. Ann Biomed Eng 2004;32:391-397. [PubMed: 15095813]

123. Smeds KA, Pfister-Serres A, Miki D, Dastgheib K, Inoue M, Hatchell DL, Grinstaff MW. Photocrosslinkable polysaccharides for in situ hydrogel formation. J Biomed Mater Res 2001;54:115-121. [PubMed: 11077410]

124. Burdick JA, Chung C, Jia XQ, Randolph MA, Langer R. Controlled degradation and mechanical behavior of photopolymerized hyaluronic acid networks. Biomacromolecules 2005;6:386-391. [PubMed: 15638543]

125. Chung C, Mesa J, Randolph MA, Yaremchuk M, Burdick JA. Influence of gel properties on neocartilage formation by auricular chondrocytes photoencapsulated in hyaluronic acid networks. J Biomed Mater Res A 2006;77:518-525. [PubMed: 16482551]

126. Liu YC, Shu XZ, Prestwich GD. Osteochondral defect repair with autologous bone marrow-derived mesenchymal stem cells in an injectable, in situ, cross-linked synthetic extracellular matrix. Tissue Engineering 2006;12:3405-3416. [PubMed: 17518677]

127. Li Q, Williams CG, Sun DD, Wang J, Leong K, Elisseeff JH. Photocrosslinkable polysaccharides based on chondroitin sulfate. J Biomed Mater Res A 2004;68:28-33. [PubMed: 14661246]

128. Mosesson MW. Fibrinogen and fibrin structure and functions. J Thromb Haemost 2005;3:18941904. [PubMed: 16102057]

129. Eyrich D, Brandl F, Appel B, Wiese H, Maier G, Wenzel M, Staudenmaier R, Goepferich A, Blunk T. Long-term stable fibrin gels for cartilage engineering. Biomaterials 2007;28:55-65. [PubMed: 16962167]

130. Silverman RP, Passaretti D, Huang W, Randolph MA, Yaremchuk MJ. Injectable tissue-engineered cartilage using a fibrin glue polymer. Plast Reconstr Surg 1999;103:1809-1818. [PubMed: 10359239]

131. Lee CR, Grad S, Gorna K, Gogolewski S, Goessl A, Alini M. Fibrin-polyurethane composites for articular cartilage tissue engineering: A preliminary analysis. Tissue Engineering 2005;11:15621573. [PubMed: 16259610]

132. De Franceschi L, Grigolo B, Roseti L, Facchini A, Fini M, Giavaresi G, Tschon M, Giardino R. Transplantation of chondrocytes seeded on collagen-based scaffold in cartilage defects in rabbits. Journal of Biomedical Materials Research Part A 2005;75A:612-622. [PubMed: 16108031]

133. Hoshikawa A, Nakayama Y, Matsuda T, Oda H, Nakamura K, Mabuchi K. Encapsulation of chondrocytes in photopolymerizable styrenated gelatin for cartilage tissue engineering. Tissue Engineering 2006;12:2333-2341. [PubMed: 16968173]

134. Schagemann JC, Mrosek EH, Landers R, Kurz H, Erggelet C. Morphology and function of ovine articular cartilage chondrocytes in 3-D hydrogel culture. Cells Tissues Organs 2006;182:89-97. [PubMed: 16804299]

135. Connelly JT, Garcia AJ, Levenston ME. Inhibition of in vitro chondrogenesis in RGD-modified three-dimensional alginate gels. Biomaterials 2007;28:1071-1083. [PubMed: 17123602]

136. Iwasaki N, Yamane ST, Majima T, Kasahara Y, Minami A, Harada K, Nonaka S, Maekawa N, Tamura H, Tokura S, Shiono M, Monde K, Nishimura SI. Feasibility of polysaccharide hybrid materials for scaffolds in cartilage tissue engineering: Evaluation of chondrocyte adhesion to polyion complex fibers prepared from alginate and chitosan. Biomacromolecules 2004;5:828-833. [PubMed: 15132668]

137. Wayne JS, McDowell CL, Shields KJ, Tuan RS. In vivo response of polylactic acid-alginate scaffolds and bone marrow-derived cells for cartilage tissue engineering. Tissue Engineering 2005; 11 :953963. [PubMed: 15998234] 
138. Genes NG, Rowley JA, Mooney DJ, Bonassar LJ. Effect of substrate mechanics on chondrocyte adhesion to modified alginate surfaces. Arch Biochem Biophys 2004;422:161-167. [PubMed: 14759603]

139. Mauck RL, Soltz MA, Wang CCB, Wong DD, Chao PHG, Valhmu WB, Hung CT, Ateshian GA. Functional tissue engineering of articular cartilage through dynamic loading of chondrocyte-seeded agarose gels. Journal of Biomechanical Engineering-Transactions of the Asme 2000;122:252-260.

140. Sechriest VF, Miao YJ, Niyibizi C, Westerhausen-Larson A, Matthew HW, Evans CH, Fu FH, Suh JK. GAG-augmented polysaccharide hydrogel: A novel biocompatible and biodegradable material to support chondrogenesis. Journal of Biomedical Materials Research 1999;49:534-541. [PubMed: 10602087]

141. Subramanian A, Lin HY. Crosslinked chitosan: Its physical properties and the effects of matrix stiffness on chondrocyte cell morphology and proliferation. Journal of Biomedical Materials Research Part A 2005;75A:742-753. [PubMed: 16110496]

142. Chen JP, Cheng TH. Thermo-responsive chitosan-graft-poly( $\mathrm{N}$-isopropylacrylamide) injectable hydrogel for cultivation of chondrocytes and meniscus cells. Macromolecular Bioscience 2006;6:1026-1039. [PubMed: 17128421]

143. Au A, Ha J, Polotsky A, Krzyminski K, Gutowska A, Hungerford DS, Frondoza CG. Thermally reversible polymer gel for chondrocyte culture. Journal of Biomedical Materials Research Part A 2003;67A:1310-1319. [PubMed: 14624518]

144. Fisher JP, Jo S, Mikos AG, Reddi AH. Thermoreversible hydrogel scaffolds for articular cartilage engineering. Journal of Biomedical Materials Research Part A 2004;71A:268-274. [PubMed: 15368220]

145. Na K, Kim S, Woo DG, Sun BK, Yang HN, Chung HM, Park KH. Synergistic effect of TGF beta-3 on chondrogenic differentiation of rabbit chondrocytes in thermo-reversible hydrogel constructs blended with hyaluronic acid by in vivo test. Journal of Biotechnology 2007;128:412-422. [PubMed: 17098315]

146. Holmes TC. Novel peptide-based biomaterial scaffolds for tissue engineering. Trends Biotechnol 2002;20:16-21. [PubMed: 11742673]

147. Zhang S, Holmes T, Lockshin C, Rich A. Spontaneous assembly of a self-complementary oligopeptide to form a stable macroscopic membrane. Proc Natl Acad Sci U S A 1993;90:33343338. [PubMed: 7682699]

148. Kisiday J, Jin M, Kurz B, Hung H, Semino C, Zhang S, Grodzinsky AJ. Self-assembling peptide hydrogel fosters chondrocyte extracellular matrix production and cell division: implications for cartilage tissue repair. Proc Natl Acad Sci U S A 2002;99:9996-10001. [PubMed: 12119393]

149. Kisiday JD, Jin MS, DiMicco MA, Kurz B, Grodzinsky AJ. Effects of dynamic compressive loading on chondrocyte biosynthesis in self-assembling peptide scaffolds. Journal of Biomechanics 2004;37:595-604. [PubMed: 15046988]

150. Bhardwaj T, Pilliar RM, Grynpas MD, Kandel RA. Effect of material geometry on cartilagenous tissue formation in vitro. Journal of Biomedical Materials Research 2001;57:190-199. [PubMed: 11484181]

151. Hile DD, Amirpour ML, Akgerman A, Pishko MV. Active growth factor delivery from poly(D,Llactide-co-glycolide) foams prepared in supercritical CO(2). J Control Release 2000;66:177-185. [PubMed: 10742578]

152. Sato T, Chen GP, Ushida T, Ishii T, Ochiai N, Tateishi T, Tanaka J. Evaluation of PLLA-collagen hybrid sponge as a scaffold for cartilage tissue engineering. Materials Science \& Engineering CBiomimetic and Supramolecular Systems 2004;24:365-372.

153. Chen GP, Sato T, Ushida T, Ochiai N, Tateishi T. Tissue engineering of cartilage using a hybrid scaffold of synthetic polymer and collagen. Tissue Engineering 2004;10:323-330. [PubMed: 15165449]

154. Miralles G, Baudoin R, Dumas D, Baptiste D, Hubert P, Stoltz JF, Dellacherie E, Mainard D, Netter $P$, Payan E. Sodium alginate sponges with or without sodium hyaluronate: In vitro engineering of cartilage. Journal of Biomedical Materials Research 2001;57:268-278. [PubMed: 11484190] 
155. Barnewitz D, Endres M, Kruger I, Becker A, Zimmermann M, Wilke I, Ringe J, Sittinger M, Kaps C. Treatment of articular cartilage defects in horses with polymer-based cartilage tissue engineering grafts. Biomaterials 2006;27:2882-2889. [PubMed: 16442157]

156. Kuo YC, Lin CY. Effect of genipin-crosslinked chitin-chitosan scaffolds with hydroxyapatite modifications on the cultivation of bovine knee chondrocytes. Biotechnology and Bioengineering 2006;95:132-144. [PubMed: 16739223]

157. Nettles DL, Elder SH, Gilbert JA. Potential use of chitosan as a cell scaffold material for cartilage tissue engineering. Tissue Engineering 2002;8:1009-1016. [PubMed: 12542946]

158. Xia WY, Liu W, Cui L, Liu YC, Zhong W, Liu DL, Wu JJ, Chua KH, Cao YL. Tissue engineering of cartilage with the use of chitosan-gelatin complex scaffolds. Journal of Biomedical Materials Research Part B-Applied Biomaterials 2004;71B:373-380.

159. Hofmann S, Knecht S, Langer R, Kaplan DL, Vunjak-Novakovic G, Merkle HP, Meinel L. Cartilagelike tissue engineering using silk scaffolds and mesenchymal stem cells. Tissue Engineering 2006;12:2729-2738. [PubMed: 17518642]

160. Wang YZ, Kim HJ, Vunjak-Novakovic G, Kaplan DL. Stem cell-based tissue engineering with silk biomaterials. Biomaterials 2006;27:6064-6082. [PubMed: 16890988]

161. Vickers SM, Squitieri LS, Spector M. Effects of cross-linking type II collagen-GAG scaffolds on chondrogenesis in vitro: Dynamic pore reduction promotes cartilage formation. Tissue Engineering 2006;12:1345-1355. [PubMed: 16771647]

162. Goodstone NJ, Cartwright A, Ashton B. Effects of high molecular weight hyaluronan on chondrocytes cultured within a resorbable gelatin sponge. Tissue Engineering 2004;10:621-631. [PubMed: 15165478]

163. Kang Y, Yang J, Khan S, Anissian L, Ameer GA. A new biodegradable polyester elastomer for cartilage tissue engineering. Journal of Biomedical Materials Research Part A 2006;77A:331-339. [PubMed: 16404714]

164. Wang YZ, Blasioli DJ, Kim HJ, Kim HS, Kaplan DL. Cartilage tissue engineering with silk scaffolds and human articular chondrocytes. Biomaterials 2006;27:4434-4442. [PubMed: 16677707]

165. Chen GP, Sato T, Ushida T, Hirochika R, Shirasaki Y, Ochiai N, Tateishi T. The use of a novel PLGA fiber/collagen composite web as a scaffold for engineering of articular cartilage tissue with adjustable thickness. Journal of Biomedical Materials Research Part A 2003;67A:1170-1180. [PubMed: 14624503]

166. Woodfield TB, Malda J, de Wijn J, Peters F, Riesle J, van Blitterswijk CA. Design of porous scaffolds for cartilage tissue engineering using a three-dimensional fiber-deposition technique. Biomaterials 2004;25:4149-4161. [PubMed: 15046905]

167. Moroni L, de Wijn JR, van Blitterswijk CA. 3D fiber-deposited scaffolds for tissue engineering: influence of pores geometry and architecture on dynamic mechanical properties. Biomaterials 2006;27:974-985. [PubMed: 16055183]

168. Moroni L, Hendriks JAA, Schotel R, De Wijn JR, Van Blitterswijk CA. Design of biphasic polymeric 3-dimensional fiber deposited scaffolds for cartilage tissue engineering applications. Tissue Engineering 2007;13:361-371. [PubMed: 17504063]

169. Li WJ, Danielson KG, Alexander PG, Tuan RS. Biological response of chondrocytes cultured in three-dimensional nanofibrous poly(epsilon-caprolactone) scaffolds. Journal of Biomedical Materials Research Part A 2003;67A:1105-1114. [PubMed: 14624495]

170. Shin HJ, Lee CH, Cho IH, Kim YJ, Lee YJ, Kim IA, Park KD, Yui N, Shin JW. Electrospun PLGA nanofiber scaffolds for articular cartilage reconstruction: mechanical stability, degradation and cellular responses under mechanical stimulation in vitro. Journal of Biomaterials Science-Polymer Edition 2006;17:103-119. [PubMed: 16411602]

171. Hsu SH, Chang SH, Yen HJ, Whu SW, Tsai CL, Chen DC. Evaluation of biodegradable polyesters modified by type II collagen and Arg-Gly-Asp as tissue engineering scaffolding materials for cartilage regeneration. Artificial Organs 2006;30:42-55. [PubMed: 16409397]

172. Yoo HS, Lee EA, Yoon JJ, Park TG. Hyaluronic acid modified biodegradable scaffolds for cartilage tissue engineering. Biomaterials 2005;26:1925-1933. [PubMed: 15576166] 
173. Uematsu K, Hattori K, Ishimoto Y, Yamauchi J, Habata T, Takakura Y, Ohgushi H, Fukuchi T, Sato M. Cartilage regeneration using mesenchymal stem cells and a three-dimensional poly-lacticglycolic acid (PLGA) scaffold. Biomaterials 2005;26:4273-4279. [PubMed: 15683651]

174. Muller FA, Muller L, Hofmann I, Greil P, Wenzel MM, Staudenmaier R. Cellulose-based scaffold materials for cartilage tissue engineering. Biomaterials 2006;27:3955-3963. [PubMed: 16530823]

175. Girotto D, Urbani S, Brun P, Renier D, Barbucci R, Abatangelo G. Tissue-specific gene expression in chondrocytes grown on three-dimensional hyaluronic acid scaffolds. Biomaterials 2003;24:3265-3275. [PubMed: 12763454]

176. Grigolo B, Lisignoli G, Piacentini A, Fiorini M, Gobbi P, Mazzotti G, Duca M, Pavesio A, Facchini A. Evidence for redifferentiation of human chondrocytes grown on a hyaluronan-based biomaterial (HYAFF (R) 11): molecular, immunohistochemical and ultrastructural analysis. Biomaterials 2002;23:1187-1195. [PubMed: 11791922]

177. Radice M, Brun P, Cortivo R, Scapinelli R, Battaliard C, Abatangelo G. Hyaluronan-based biopolymers as delivery vehicles for bone-marrow-derived mesenchymal progenitors. Journal of Biomedical Materials Research 2000;50:101-109. [PubMed: 10679672]

178. Gobbi A, Kon E, Berruto M, Francisco R, Filardo G, Marcacci M. Patellofemoral full-thickness chondral defects treated with hyalograft-C - A clinical, arthroscopic, and histologic review. American Journal of Sports Medicine 2006;34:1763-1773. [PubMed: 16832129]

179. Hollander AP, Dickinson SC, Sims TJ, Brun P, Cortivo R, Kon E, Marcacci M, Zanasi S, Borrione A, De Luca C, Pavesio A, Soranzo C, Abatangelo G. Maturation of tissue engineered cartilage implanted in injured and osteoarthritic human knees. Tissue Engineering 2006;12:1787-1798. [PubMed: 16889509]

180. Marcacci M, Berruto M, Brocchetta D, Delcogliano A, Ghinelli D, Gobbi A, Kon E, Pederzini L, Rosa D, Sacchetti GL, Stefani G, Zanasi S. Articular cartilage engineering with Hyalograft (R) C - 3-year clinical results. Clinical Orthopaedics and Related Research 2005:96-105. [PubMed: 15930926]

181. Kellner K, Schulz MB, Gopferich A, Blunk T. Insulin in tissue engineering of cartilage: A potential model system for growth factor application. Journal of Drug Targeting 2001;9:439-448. [PubMed: 11822816]

182. Seyedin SM, Rosen DM, Segarini PR. Modulation of chondroblast phenotype by transforming growth factor-beta. Pathol Immunopathol Res 1988;7:38-42. [PubMed: 2906121]

183. Iwasaki M, Nakata K, Nakahara H, Nakase T, Kimura T, Kimata K, Caplan AI, Ono K. Transforming growth factor-beta 1 stimulates chondrogenesis and inhibits osteogenesis in high density culture of periosteum-derived cells. Endocrinology 1993;132:1603-1608. [PubMed: 8462458]

184. Kim SE, Park JH, Cho YW, Chung H, Jeong SY, Lee EB, Kwon IC. Porous chitosan scaffold containing microspheres loaded with transforming growth factor-beta 1: Implications for cartilage tissue engineering. Journal of Controlled Release 2003;91:365-374. [PubMed: 12932714]

185. Rosier RN, O' Keefe RJ, Crabb ID, Puzas JE. Transforming growth factor beta: an autocrine regulator of chondrocytes. Connect Tissue Res 1989;20:295-301. [PubMed: 2612160]

186. Vivien D, Galera P, Lebrun E, Loyau G, Pujol JP. Differential effects of transforming growth factorbeta and epidermal growth factor on the cell cycle of cultured rabbit articular chondrocytes. J Cell Physiol 1990;143:534-545. [PubMed: 2358472]

187. Tuli R, Tuli S, Nandi S, Huang X, Manner PA, Hozack WJ, Danielson KG, Hall DJ, Tuan RS. Transforming growth factor-beta-mediated chondrogenesis of human mesenchymal progenitor cells involves N-cadherin and mitogen-activated protein kinase and Wnt signaling cross-talk. J Biol Chem 2003;278:41227-41236. [PubMed: 12893825]

188. Gooch KJ, Kwon JH, Blunk T, Langer R, Freed LE, Vunjak-Novakovic G. Effects of mixing intensity on tissue-engineered cartilage. Biotechnology and Bioengineering 2001;72:402-407. [PubMed: 11180060]

189. Roberts AB, Kondaiah P, Rosa F, Watanabe S, Good P, Danielpour D, Roche NS, Rebbert ML, Dawid IB, Sporn MB. Mesoderm induction in Xenopus laevis distinguishes between the various TGF-beta isoforms. Growth Factors 1990;3:277-286. [PubMed: 2257149] 
190. Gooch KJ, Blunk T, Courter DL, Sieminski AL, Bursac PM, Vunjak-Novakovic G, Freed LE. IGFI and mechanical environment interact to modulate engineered cartilage development. Biochemical and Biophysical Research Communications 2001;286:909-915. [PubMed: 11527385]

191. Martin I, Suetterlin R, Baschong W, Heberer M, Vunjak-Novakovic G, Freed LE. Enhanced cartilage tissue engineering by sequential exposure of chrondrocytes to FGF-2 during 2D expansion and BMP-2 during 3D cultivation. Journal of Cellular Biochemistry 2001;83:121-128. [PubMed: 11500960]

192. Miot S, de Freitas PS, Wirz D, Daniels AU, Sims TJ, Hollander AP, Mainil-Varlet P, Heberer M, Martin I. Cartilage tissue engineering by expanded goat articular chondrocytes. Journal of Orthopaedic Research 2006;24:1078-1085. [PubMed: 16583449]

193. Schmal H, Mehlhorn AT, Zwingmann J, Muller CA, Stark GB, Sudkamp NP. Stimulation of chondrocytes in vitro by gene transfer with plasmids coding for epidermal growth factor (hEGF) and basic fibroblast growth factor (bFGF). Cytotherapy 2005;7:292-300. [PubMed: 16081356]

194. Stevens MM, Marini RP, Martin I, Langer R, Shastri VP. FGF-2 enhances TGF-beta 1-induced periosteal chondrogenesis. Journal of Orthopaedic Research 2004;22:1114-1119. [PubMed: 15304287]

195. Veilleux N, Spector M. Effects of FGF-2 and IGF-1 on adult canine articular chondrocytes in type II collagen-glycosaminoglycan scaffolds in vitro. Osteoarthritis and Cartilage 2005;13:278-286. [PubMed: 15780641]

196. Fujisato T, Sajiki T, Liu Q, Ikada Y. Effect of basic fibroblast growth factor on cartilage regeneration in chondrocyte-seeded collagen sponge scaffold. Biomaterials 1996;17:155-162. [PubMed: 8624392]

197. Frenkel SR, Saadeh PB, Mehrara BJ, Chin GS, Steinbrech DS, Brent B, Gittes GK, Longker MT. Transforming growth factor beta superfamily members: Role in cartilage modeling. Plastic and Reconstructive Surgery 2000;105:980-990. [PubMed: 10724258]

198. Hicks DL, Sage AB, Shelton E, Schumacher BL, Sah RL, Watson D. Effect of bone morphogenetic proteins 2 and 7 on septal chondrocytes in alginate. Otolaryngology-Head and Neck Surgery 2007;136:373-379. [PubMed: 17321862]

199. Kaps C, Bramlage C, Smolian H, Haisch A, Ungethum U, Burmester GR, Sittinger M, Gross G, Haupl T. Bone morphogenetic proteins promote cartilage differentiation and protect engineered artificial cartilage from fibroblast invasion and destruction. Arthritis and Rheumatism 2002;46:149162. [PubMed: 11817587]

200. Mason JM, Breitbart AS, Barcia M, Porti D, Pergolizzi RG, Grande DA. Cartilage and bone regeneration using gene-enhanced tissue engineering. Clinical Orthopaedics and Related Research 2000:S171-S178. [PubMed: 11039767]

201. Holland TA, Tabata Y, Mikos AG. Dual growth factor delivery from degradable oligo(poly(ethylene glycol) fumarate) hydrogel scaffolds for cartilage tissue engineering. Journal of Controlled Release 2005;101:111-125. [PubMed: 15588898]

202. Park H, Temenoff JS, Holland TA, Tabata Y, Mikos AG. Delivery of TGF-beta 1 and chondrocytes via injectable, biodegradable hydrogels for cartilage tissue engineering applications. Biomaterials 2005;26:7095-7103. [PubMed: 16023196]

203. Sharma B, Williams CG, Khan M, Manson P, Elisseeff JH. In vivo chondrogenesis of mesenchymal stem cells in a photopolymerized hydrogel. Plastic and Reconstructive Surgery 2007;119:112-120. [PubMed: 17255664]

204. Huang Q, Hutmacher DW, Lee EH. In vivo mesenchymal cell recruitment by a scaffold loaded with transforming growth factor beta 1 and the potential for in situ chondrogenesis. Tissue Engineering 2002;8:469-482. [PubMed: 12167232]

205. DeFail AJ, Chu CR, Izzo N, Marra KG. Controlled release of bioactive TGF-beta(1) from microspheres embedded within biodegradable hydrogels. Biomaterials 2006;27:1579-1585. [PubMed: 16140372]

206. Lee JE, Kim SE, Kwon IC, Ahn HJ, Cho H, Lee SH, Kim HJ, Seong SC, Lee MC. Effects of a chitosan scaffold containing TGF-beta 1 encapsulated chitosan microspheres on in vitro chondrocyte culture. Artificial Organs 2004;28:829-839. [PubMed: 15320946] 
207. Mauck RL, Nicoll SB, Seyhan SL, Ateshian GA, Hung CT. Synergistic action of growth factors and dynamic loading for articular cartilage tissue engineering. Tissue Engineering 2003;9:597-611. [PubMed: 13678439]

208. Holland TA, Bodde EWH, Cuijpers VMJI, Baggett LS, Tabata Y, Mikos AG, Jansen JA. Degradable hydrogel scaffolds for in vivo delivery of single and dual growth factors in cartilage repair. Osteoarthritis and Cartilage 2007;15:187-197. [PubMed: 16965923]

209. Allemann M, Mizuno S, Eid K, Yates KE, Zaleske D, Glowacki J. Effects of hyaluronan on engineered articular cartilage extracellular matrix gene expression in 3-dimensional collagen scaffolds. Journal of Biomedical Materials Research 2001;55:13-19. [PubMed: 11426390]

210. Yamane S, Iwasaki N, Majima T, Funakoshi T, Masuko T, Harada K, Minami A, Monde K, Nishimura S. Feasibility of chitosan-based hyaluronic acid hybrid biomaterial for a novel scaffold in cartilage tissue engineering. Biomaterials 2005;26:611-619. [PubMed: 15282139]

211. Buma P, Pieper JS, van Tienen T, van Susante JLC, van der Kraan PM, Veerkamp JH, van den Berg WB, Veth RPH, van Kuppevelt TH. Cross-linked type I and type II collagenous matrices for the repair of full-thickness articular cartilage defects - A study in rabbits. Biomaterials 2003;24:32553263. [PubMed: 12763453]

212. Asanbaeva A, Masuda K, Thonar EJMA, Klisch SM, Sah RL. Mechanisms of cartilage growth Modulation of balance between proteoglycan and collagen in vitro using chondroitinase ABC. Arthritis and Rheumatism 2007;56:188-198. [PubMed: 17195221]

213. Saraf A, Mikos AG. Gene delivery strategies for cartilage tissue engineering. Advanced Drug Delivery Reviews 2006;58:592-603. [PubMed: 16766079]

214. Madry H, Kaul G, Cucchiarini M, Stein U, Zurakowski D, Remberger K, Menger MD, Kohn D, Trippel SB. Enhanced repair of articular cartilage defects in vivo by transplanted chondrocytes overexpressing insulin-like growth factor I (IGF-I). Gene Ther 2005;12:1171-1179. [PubMed: 15815701]

215. Tong JC, Yao SL. Novel scaffold containing transforming growth factor-beta 1 DNA for cartilage tissue engineering. Journal of Bioactive and Compatible Polymers 2007;22:232-244.

216. Grande DA, Mason J, Light E, Dines D. Stem cells as platforms for delivery of genes to enhance cartilage repair. Journal of Bone and Joint Surgery-American 2003;85A:111-116.

217. Hansen U, Schunke M, Domm C, Ioannidis N, Hassenpflug J, Gehrke T, Kurz B. Combination of reduced oxygen tension and intermittent hydrostatic pressure: a useful tool in articular cartilage tissue engineering. Journal of Biomechanics 2001;34:941-949. [PubMed: 11410177]

218. Scherer K, Schunke M, Sellckau R, Hassenpflug J, Kurz B. The influence of oxygen and hydrostatic pressure on articular chondrocytes and adherent bone marrow cells in vitro. Biorheology 2004;41:323-333. [PubMed: 15299265]

219. Miyanishi K, Trindade MCD, Lindsey DP, Beaupre GS, Carter DR, Goodman SB, Schurman DJ, Smith RL. Dose- and time-dependent effects of cyclic hydrostatic pressure on transforming growth factor-beta 3-induced chondrogenesis by adult human mesenchymal stem cells in vitro. Tissue Engineering 2006;12:2253-2262. [PubMed: 16968165]

220. Miyanishi K, Trindade MCD, Lindsey DP, Beaupre GS, Carter DR, Goodman SB, Schurman DJ, Smith RL. Effects of hydrostatic pressure and transforming growth factor-beta 3 on adult human mesenchymal stem cell chondrogenesis in vitro. Tissue Engineering 2006;12:1419-1428. [PubMed: 16846340]

221. Hu JC, Athanasiou KA. The effects of intermittent hydrostatic pressure on self-assembled articular cartilage constructs. Tissue Engineering 2006;12:1337-1344. [PubMed: 16771646]

222. De Croos JNA, Dhaliwal SS, Grynpas MD, Pilliar RM, Kandel RA. Cyclic compressive mechanical stimulation induces sequential catabolic and anabolic gene changes in chondrocytes resulting in increased extracellular matrix accumulation. Matrix Biology 2006;25:323-331. [PubMed: 16697175]

223. Waldman SD, Couto DC, Grynpas MD, Pilliar RM, Kandel RA. A single application of cyclic loading can accelerate matrix deposition and enhance the properties of tissue-engineered cartilage. Osteoarthritis and Cartilage 2006;14:323-330. [PubMed: 16324852] 
224. Davisson T, Kunig S, Chen A, Sah R, Ratcliffe A. Static and dynamic compression modulate matrix metabolism in tissue engineered cartilage. Journal of Orthopaedic Research 2002;20:842-848. [PubMed: 12168676]

225. Angele P, Schumann D, Angele M, Kinner B, Englert C, Hente R, Fuchtmeier B, Nerlich M, Neumann C, Kujat R. Cyclic, mechanical compression enhances chondrogenesis of mesenchymal progenitor cells in tissue engineering scaffolds. Biorheology 2004;41:335-346. [PubMed: 15299266]

226. Lee CR, Grodzinsky AJ, Spector A. Biosynthetic response of passaged chondrocytes in a type II collagen scaffold to mechanical compression. Journal of Biomedical Materials Research Part A 2003;64A:560-569. [PubMed: 12579571]

227. Ng KW, Mauck RL, Statman LY, Lin EY, Ateshian GA, Hung CT. Dynamic deformational loading results in selective application of mechanical stimulation in a layered, tissue-engineered cartilage construct. Biorheology 2006;43:497-507. [PubMed: 16912421]

228. Hunter CJ, Mouw JK, Levenston ME. Dynamic compression of chondrocyte-seeded fibrin gels: effects on matrix accumulation and mechanical stiffness. Osteoarthritis and Cartilage 2004;12:117130. [PubMed: 14723871]

229. Chowdhury TT, Salter DM, Bader DL, Lee DA. Integrin-mediated mechanotransduction processes in TGF beta-stimulated monolayer-expanded chondrocytes. Biochemical and Biophysical Research Communications 2004;318:873-881. [PubMed: 15147953]

230. Pazzano D, Mercier KA, Moran JM, Fong SS, DiBiasio DD, Rulfs JX, Kohles SS, Bonassar LJ. Comparison of chondrogensis in static and perfused bioreactor culture. Biotechnology Progress 2000;16:893-896. [PubMed: 11027186]

231. Xu X, Urban JPG, Tirlapur U, Wu MH, Cui Z, Cui ZF. Influence of perfusion on metabolism and matrix production by bovine articular chondrocytes in hydrogel scaffolds. Biotechnology and Bioengineering 2006;93:1103-1111. [PubMed: 16470872]

232. Hu JC, Athanasiou KA. Low-density cultures of bovine chondrocytes: effects of scaffold material and culture system. Biomaterials 2005;26:2001-2012. [PubMed: 15576174]

233. Gemmiti CV, Guldberg RE. Fluid flow increases type II collagen deposition and tensile mechanical properties in bioreactor-grown tissue-engineered cartilage. Tissue Engineering 2006;12:469-479. [PubMed: 16579680]

234. Saini S, Wick TM. Concentric cylinder bioreactor for production of tissue engineered cartilage: Effect of seeding density and hydrodynamic loading on construct development. Biotechnology Progress 2003;19:510-521. [PubMed: 12675595]

235. Bueno EM, Bilgen B, Barabino GA. Wavy-walled bioreactor supports increased cell proliferation and matrix deposition in engineered cartilage constructs. Tissue Engineering 2005;11:1699-1709. [PubMed: 16411815]

236. Brittberg M, Lindahl A, Nilsson A, Ohlsson C, Isaksson O, Peterson L. Treatment of deep cartilage defects in the knee with autologous chondrocyte transplantation. N Engl J Med 1994;331:889-895. [PubMed: 8078550]

237. Vunjak-Novakovic G, Martin I, Obradovic B, Treppo S, Grodzinsky AJ, Langer R, Freed LE. Bioreactor cultivation conditions modulate the composition and mechanical properties of tissueengineered cartilage. J Orthop Res 1999;17:130-138. [PubMed: 10073657]

238. Kato Y, Gospodarowicz D. Sulfated Proteoglycan Synthesis by Confluent Cultures of Rabbit Costal Chondrocytes Grown in the Presence of Fibroblast Growth-Factor. Journal of Cell Biology 1985;100:477-485. [PubMed: 3968172]

239. Yoo JU, Barthel TS, Nishimura K, Solchaga L, Caplan AI, Goldberg VM, Johnstone B. The chondrogenic potential of human bone-marrow-derived mesenchymal progenitor cells. J Bone Joint Surg Am 1998;80:1745-1757. [PubMed: 9875932]

240. Kuroda R, Usas A, Kubo S, Corsi K, Peng HR, Rose T, Cummins J, Fu FH, Huard J. Cartilage repair using bone morphogenetic protein 4 and muscle-derived stem cells. Arthritis and Rheumatism 2006;54:433-442. [PubMed: 16447218]

241. Nakata K, Nakahara H, Kimura T, Kojima A, Iwasaki M, Caplan AI, Ono K. Collagen GeneExpression during Chondrogenesis from Chick Periosteum-Derived Cells. Febs Letters 1992;299:278-282. [PubMed: 1544506] 
242. Park J, Gelse K, Frank S, von der Mark K, Aigner T, Schneider H. Transgene-activated mesenchymal cells for articular cartilage repair: a comparison of primary bone marrow-, perichondrium/ periosteum- and fat-derived cells. Journal of Gene Medicine 2006;8:112-125. [PubMed: 16142704]

243. Buschmann MD, Gluzband YA, Grodzinsky AJ, Hunziker EB. Mechanical compression modulates matrix biosynthesis in chondrocyte/agarose culture. J Cell Sci 1995;108(Pt 4):1497-1508. [PubMed: 7615670]

244. Hauselmann HJ, Fernandes RJ, Mok SS, Schmid TM, Block JA, Aydelotte MB, Kuettner KE, Thonar EJ. Phenotypic stability of bovine articular chondrocytes after long-term culture in alginate beads. J Cell Sci 1994;107(Pt 1):17-27. [PubMed: 8175906]

245. Lee CR, Breinan HA, Nehrer S, Spector M. Articular cartilage chondrocytes in type I and type II collagen-GAG matrices exhibit contractile behavior in vitro. Tissue Engineering 2000;6:555-565. [PubMed: 11074941]

246. Chang CH, Liu HC, Lin CC, Chou CH, Lin FH. Gelatin-chondroitin-hyaluronan tri-copolymer scaffold for cartilage tissue engineering. Biomaterials 2003;24:4853-4858. [PubMed: 14530082]

247. Ting V, Sims CD, Brecht LE, McCarthy JG, Kasabian AK, Connelly PR, Elisseeff J, Gittes GK, Longaker MT. In vitro prefabrication of human cartilage shapes using fibrin glue and human chondrocytes. Ann Plast Surg 1998;40:413-420. [PubMed: 9555998]discussion 420-411

248. Ibusuki S, Fujii Y, Iwamoto Y, Matsuda T. Tissue-engineered cartilage using an injectable and in situ gelable thermoresponsive gelatin: fabrication and in vitro performance. Tissue Eng 2003;9:371384. [PubMed: 12740100]

249. Freed LE, Marquis JC, Nohria A, Emmanual J, Mikos AG, Langer R. Neocartilage formation in vitro and in vivo using cells cultured on synthetic biodegradable polymers. J Biomed Mater Res 1993;27:11-23. [PubMed: 8380593]

250. Li WJ, Laurencin CT, Caterson EJ, Tuan RS, Ko FK. Electrospun nanofibrous structure: a novel scaffold for tissue engineering. J Biomed Mater Res 2002;60:613-621. [PubMed: 11948520]

251. Sittinger M, Reitzel D, Dauner M, Hierlemann H, Hammer C, Kastenbauer E, Planck H, Burmester GR, Bujia J. Resorbable polyesters in cartilage engineering: Affinity and biocompatibility of polymer fiber structures to chondrocytes. Journal of Biomedical Materials Research 1996;33:5763. [PubMed: 8736023]

252. Bryant SJ, Bender RJ, Durand KL, Anseth KS. Encapsulating Chondrocytes in degrading PEG hydrogels with high modulus: Engineering gel structural changes to facilitate cartilaginous tissue production. Biotechnology and Bioengineering 2004;86:747-755. [PubMed: 15162450]

253. Elisseeff J, McIntosh W, Anseth K, Riley S, Ragan P, Langer R. Photoencapsulation of chondrocytes in poly(ethylene oxide)-based semi-interpenetrating networks. Journal of Biomedical Materials Research 2000;51:164-171. [PubMed: 10825215]

254. Song E, Kim SY, Chun T, Byun HJ, Lee YM. Collagen scaffolds derived from a marine source and their biocompatibility. Biomaterials 2006;27:2951-2961. [PubMed: 16457878]

255. Liao E, Yaszemski M, Krebsbach P, Hollister S. Tissue-engineered cartilage constructs using composite hyaluronic acid/collagen I hydrogels and designed poly(propylene fumarate) scaffolds. Tissue Engineering 2007;13:537-550. [PubMed: 17319795]

256. Chia SL, Gorna K, Gogolewski S, Alini M. Biodegradable elastomeric polyurethane membranes as chondrocyte carriers for cartilage repair. Tissue Eng 2006;12:1945-1953. [PubMed: 16889524]

257. Grad S, Kupcsik L, Gorna K, Gogolewski S, Alini M. The use of biodegradable polyurethane scaffolds for cartilage tissue engineering: potential and limitations. Biomaterials 2003;24:51635171. [PubMed: 14568433]

258. Liu Y, Webb K, Kirker KR, Bernshaw NJ, Tresco PA, Gray SD, Prestwich GD. Composite articular cartilage engineered on a chondrocyte-seeded aliphatic polyurethane sponge. Tissue Eng 2004;10:1084-1092. [PubMed: 15363166]

259. Bray JC, Merrill EW. Poly(vinyl alcohol) hydrogels for synthetic articular cartilage material. J Biomed Mater Res 1973;7:431-443. [PubMed: 4745791]

260. Bryant SJ, Davis-Arehart KA, Luo N, Shoemaker RK, Arthur JA, Anseth KS. Synthesis and characterization of photopolymerized multifunctional hydrogels: Water-soluble poly(vinyl alcohol) and chondroitin sulfate macromers for chondrocyte encapsulation. Macromolecules 2004;37:67266733 . 
261. Martens PJ, Bryant SJ, Anseth KS. Tailoring the degradation of hydrogels formed from multivinyl poly(ethylene glycol) and poly(vinyl alcohol) macromers for cartilage tissue engineering. Biomacromolecules 2003;4:283-292. [PubMed: 12625723]

262. Mcquillan DJ, Handley CJ, Campbell MA, Bolis S, Milway VE, Herington AC. Stimulation of Proteoglycan Biosynthesis by Serum and Insulin-Like Growth Factor-I in Cultured Bovine Articular-Cartilage. Biochemical Journal 1986;240:423-430. [PubMed: 3545187] 


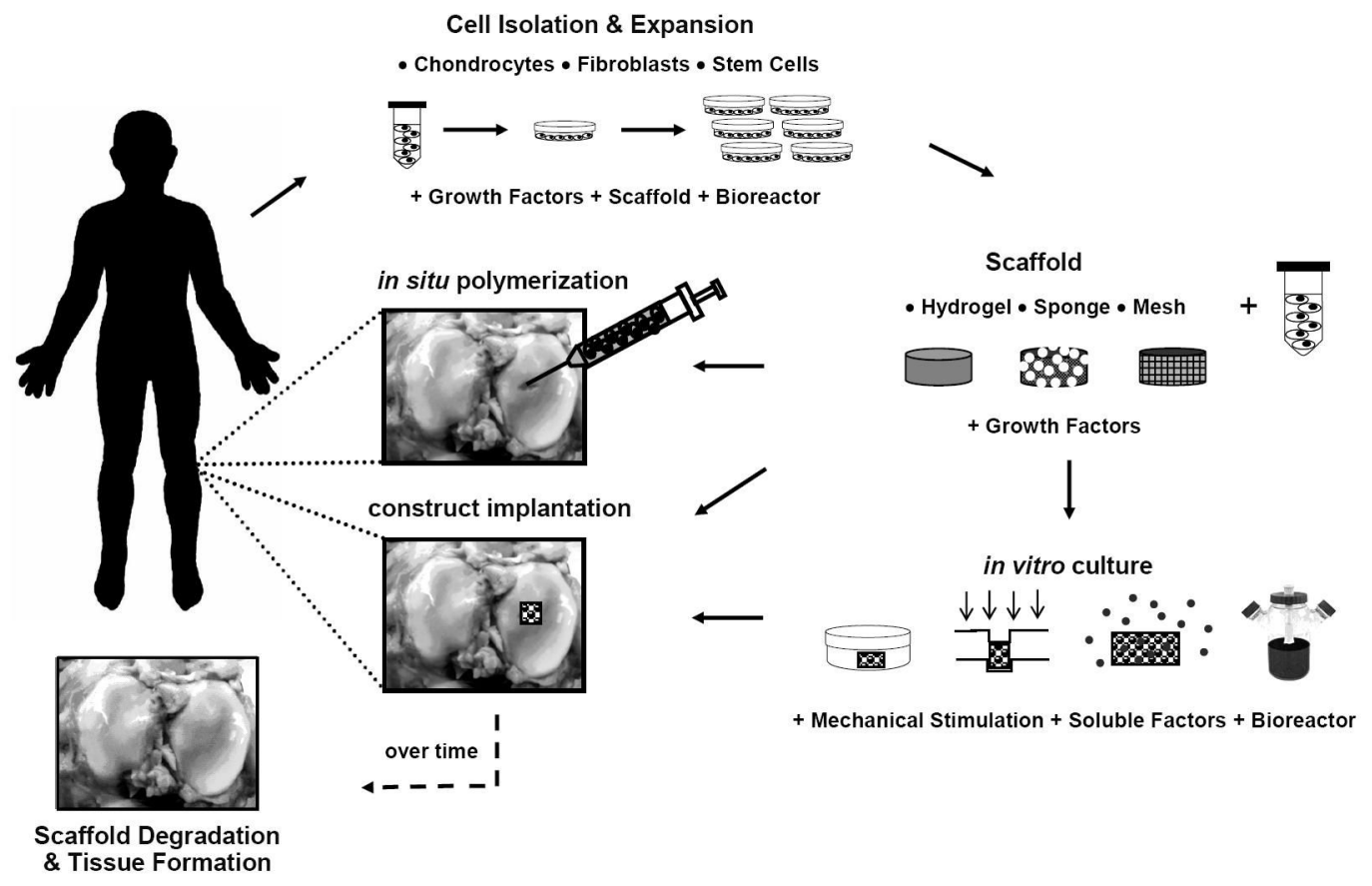

Figure 1.

General schematic of approaches used in cartilage tissue engineering, ranging from injectable systems to in vitro culture prior to implantation, and numerous biomaterials and culturing methodologies. 

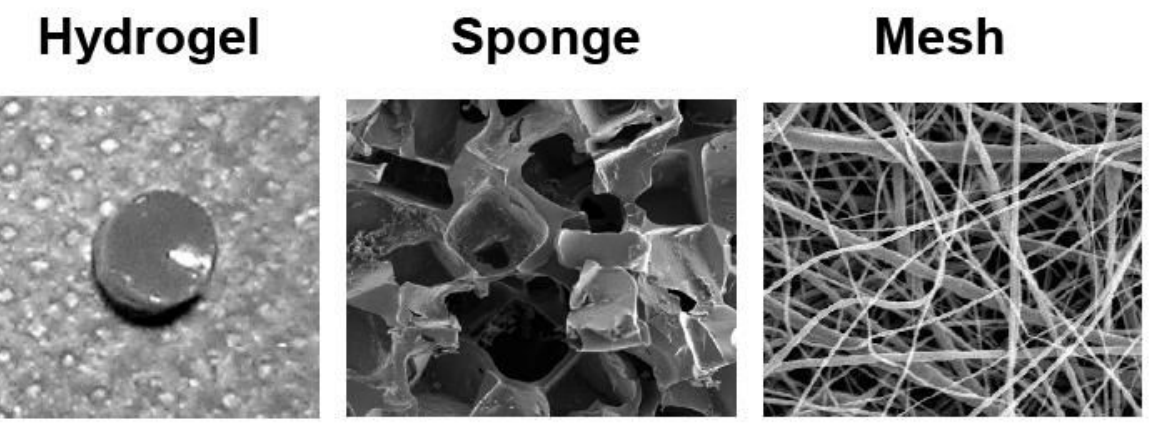

Figure 2.

Examples of different scaffold architectures used in the engineering of cartilage tissues. 
Table 1

Cell sources used in the regeneration of cartilage tissues.

\begin{tabular}{ll}
\hline Cell Source & Example References \\
\hline Chondrocytes & \\
\hline Articular & {$[32,54,57,114,139,236,237]$} \\
Auricular & {$[12,36,37,49,125]$} \\
Costal & {$[47-49,238]$} \\
Nasoseptal & {$[38,42,43,45,46]$} \\
\hline Fibroblasts & {$[4,60,62,63]$} \\
\hline Stem Cells & \\
\hline Bone-marrow derived & {$[74,80,82,91,103,239]$} \\
Adipose-derived & {$[65,93,95-97,99]$} \\
Muscle-derived & {$[66,67,240]$} \\
Synovium-derived & {$[68-70]$} \\
Periosteum-derived & {$[71,241,242]$} \\
Embryonic & {$[104-106,108,109]$} \\
\end{tabular}


Table 2

Types of biomaterials used in cartilage tissue engineering.

\begin{tabular}{ll}
\hline Biomaterial & Example References \\
\hline Natural Polymers & \\
\hline agarose & {$[17,91,139,207,243]$} \\
alginate & {$[68,83,138,154,244]$} \\
cellulose & {$[43,174]$} \\
collagen & {$[132,196,211,226,245]$} \\
chitosan & {$[140,156-158,184]$} \\
chondroitin sulfate & {$[84,127,246]$} \\
fibrin glue & {$[129-131,247]$} \\
gelatin & {$[133,158,162,248]$} \\
hyaluronic acid & {$[44,123-125,177,180]$} \\
silk fibroin & {$[76,77,159,160,164]$} \\
\hline Synthetic Polymers & \\
\hline poly( $\alpha$-hydroxy esters) & {$[169-171,173,249-251]$} \\
poly(ethylene glycol/oxide) & {$[34,74,105,110,119,252,253]$} \\
poly(NiPAAm) & {$[144,201,255]$} \\
poly(propylene fumarate) & {$[131,256-258]$} \\
poly(urethane) & {$[259-261]$} \\
poly(vinyl alcohol) & {$[146-149]$} \\
\hline Self-assembling Peptides & \\
\hline
\end{tabular}


Table 3

Stimulating factors used to induce, accelerate, or enhance cartilage formation.

\begin{tabular}{ll}
\hline Stimulating Factors & Example References \\
\hline Soluble Factors & \\
\hline BMPs & {$[198-200]$} \\
FGF-2 & {$[16,193-196]$} \\
IGF-1 & {$[71,190,208,214,262]$} \\
TGF- $\beta$ & {$[182-185,187]$} \\
chondroitin sulfate & {$[211]$} \\
hyaluronic acid & {$[154,162,209]$} \\
insulin & {$[181]$} \\
\hline Mechanical Stimulation & \\
\hline hydrostatic pressure & {$[218-221]$} \\
dynamic compression & {$[139,207,222-226]$} \\
bioreactors & {$[23,233-235]$} \\
\hline
\end{tabular}

